\title{
Survey of the Degradation Modes of Candidate Materials for High-Level Radioactive Waste Disposal Containers
}

D. W. Vinson

D. B. Bullen

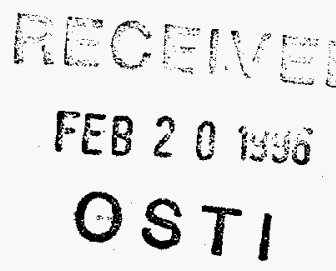

September 1995

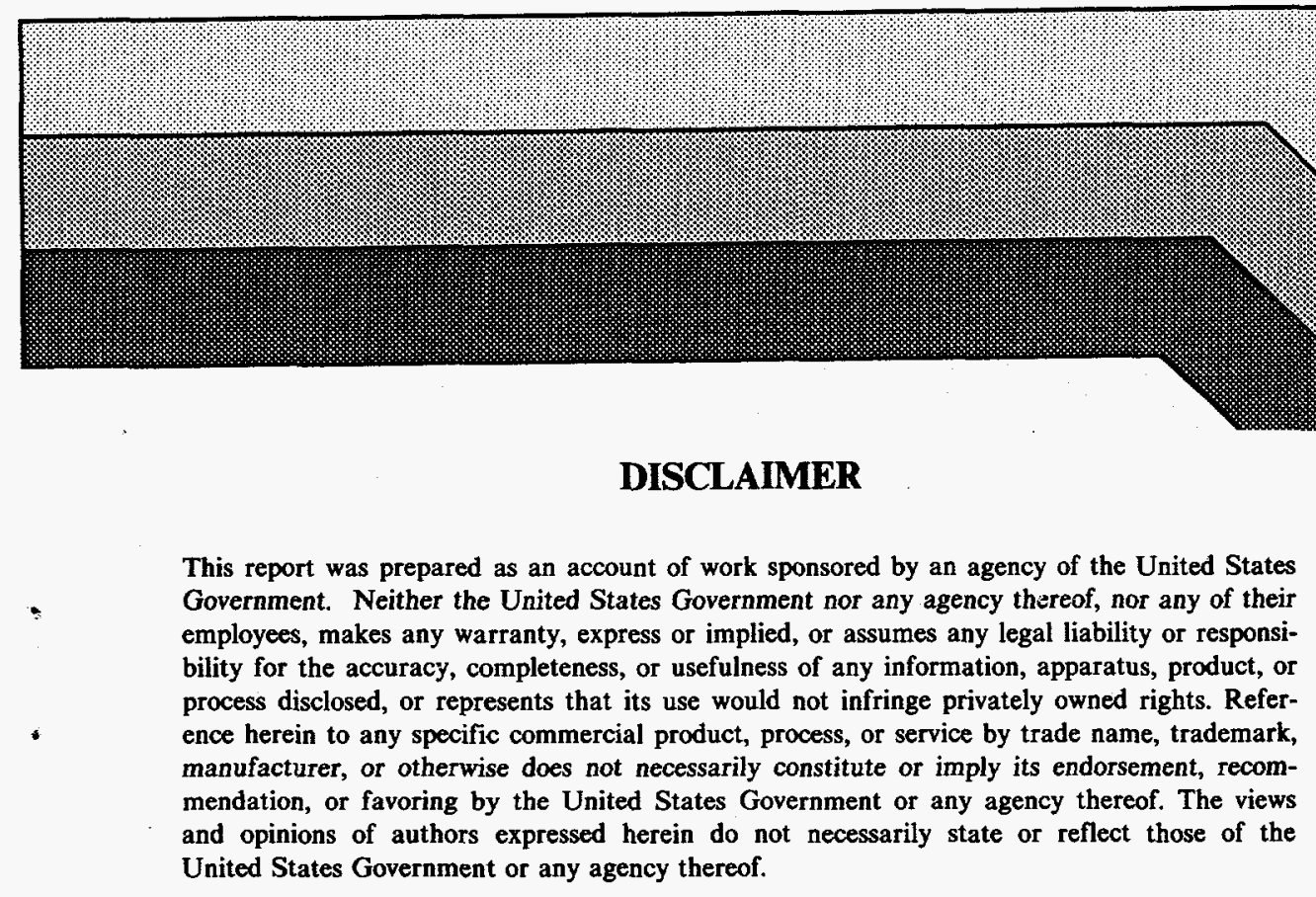


Survey of the Degradation Modes of Candidate Materials for High-Level Radioactive Waste Disposal Containers

Nickel-Copper Alloys

D.W. Vinson and D.B. Bullen Iowa State University

Nuclear Engineering Program 107 Nuclear Engineering Laboratory Ames, Iowa 50011-2241

(515) 294-9380 - Office

(515) 294-7224 - FAX

Final Report

22 September 1995

Prepared for

Dr. Edward N.C. Dalder

Chemistry \& Materials Science Department

Lawrence Livermore National Laboratory

P.O. Box 808, L-342

Livermore, California 94551

Service Subcontract No. B298419 
Table of Contents

\section{Page}

I. Introduction

II. Nickel-Copper Alloys 2

III. Oxidation and Atmospheric Corrosion 4

IV. Aqueous Corrosion 8

V. Galvanic Corrosion 15

VI. Stress Corrosion Cracking 18

$\begin{array}{ll}\text { VII. Conclusions } & 20\end{array}$

Vwi. References 22

IX. Tables 25

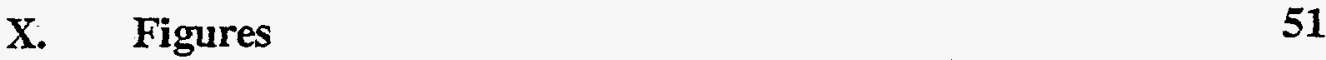


. 


\section{Introduction}

One of the most significant factors impacting the performance of waste package container materials under repository relevant conditions is the thermal environment. This environment will be affected by the areal power density of the repository, which is dictated by facility design, and the dominant heat transfer mechanism at the site. The near-field environment will evolve as radioactive decay decreases the thermal output of each waste package. Recent calculations (Buscheck and Nitao, 1994) have addressed the importance of thermal loading conditions on waste package performance at the Yucca Mountain site. If a relatively low repository thermal loading design is employed, the temperature and relative humidity near the waste package may significantly affect the degradation of corrosion allowance barriers due to moist air oxidation and radiolytically enhanced corrosion.

An evolution of the waste package design effort has resulted in an increased emphasis on the performance of the engineered barrier system (EBS). The EBS includes the waste package and the near-field engineered repository environment. This evolution has prompted research and analysis related to the development of a multiple barrier Advanced Conceptual Design (ACD) for the waste package disposal container. The ACD systems currently under consideration consist of a multiple barrier design. The outer barrier will be fabricated from a corrosion allowance material, such as carbon steel. The inner barrier will employ a corrosion resistant material, such as Alloy 825 . The thickness of each barrier is currently a variable in the container design process. The predicted long-term performance of each barrier material under repository relevant conditions will dictate the ultimate thicknesses of each barrier. Degradation modes surveys for Alloy 825 (Farmer, et al., 1988 and Gdowski, 1991) and carbon steel (Vinson, et al., 1995) have been completed previously.

A significant factor related to repository thermal performance that impacts the degradation of the container is the time period over which each container is predicted to remain dry. During this time period, a majority of the degradation of the container will occur due to simple moist air oxidation. However, current repository thermal designs include a lower thermal loading option which may result in container surface temperatures dropping below the boiling point of water in relatively short times following emplacement. This could result in a significantly more aggressive corrosion environment for the corrosion allowance material employed in the waste container. Various options addressing this potentially more aggressive environment are currently 
being considered. These options may employ an additional outer barrier that is moderately corrosion resistant under expected low thermal loading repository conditions or replacement of the carbon steel corrosion allowance barrier with a more corrosion resistant material, such as a nickel-copper alloy (Monel 400).

The estimation of long-term container performance in a deep geologic repository environment, such as the proposed site at Yucca Mountain, requires the evaluation of relevant materials degradation data. These data are required for the completion of performance assessment modeling efforts. Previous degradation modes surveys (Farmer, et al., 1988) have been completed for the six candidate materials from the Yucca Mountain Site Characterization Plan (DOE, 1988). Additional reviews of the degradation of nickel-base alloys and carbon steel were also completed by Gdowski (1991) and Vinson, et al., (1995). These surveys have been employed to identify relevant failure mechanisms for the container materials under repository relevant conditions (Farmer, et al., 1991) and to provide a relative ranking of potential container materials based upon currently available data (Van Konynenburg, et al., 1993).

The purpose this report is to present a literature review of the potential degradation modes for moderately corrosion resistant nickel copper and nickel based candidate materials that may be applicable as alternate barriers for the ACD systems in the Yucca Mountain environment. This report presents a review of the corrosion of nickel-copper alloys, summaries of experimental evaluations of oxidation and atmospheric corrosion in nickel-copper alloys, views of experimental studies of aqueous corrosion in nickel copper alloys, a brief review of galvanic corrosion effects and a summary of stress corrosion cracking in these alloys.

\section{Nickel-Copper Alloys}

Monel is primarily a corrosion resistant alloy for handling acids, alkalies, brines, waters, food products, and for atmospheric exposure (The International Nickel Company, Inc.). Table 1 contains the compositions for the Monel nickel-copper alloys. The metal finds considerable use in elevated temperature applications. According to The International Nickel Company, Inc., it does not oxidize at a destructive rate below approximately $1000^{\circ} \mathrm{F}$. The oxide scale formed on Monel is adherent and does not spall. 
Following is a summary of the characteristics of the Monel nickel-copper alloy metals compiled by Rosenberg (1968). Monel Alloy 400 gives excellent service in sea or brackish water under high-velocity conditions, as in propellers, impellers, and condenser tubes, where resistance to the effects of cavitation and erosion is important. Corrosion rates in strongly agitated and aerated sea water usually do not exceed 1 mil per year (mpy). Another important consideration in the use of the alloy in corrosion environments is its general freedom from stress-corrosion cracking.

The results of the ASTM 20-year atmospheric exposure tests of Monel Alloy 400 as reported by Rosenberg (1968) show that Alloy 400 is equally excellent in resisting the less corrosive atmospheres and is markedly superior to nickel in resistance to the industrial atmospheres of Altoona and New York City. According to Rosenberg, Monel Alloy 400 has very good resistance to oxidation at temperatures up to about $900^{\circ} \mathrm{F}$. From 900 to $1300^{\circ} \mathrm{F}$ the surface scale is still thin and very adherent, but grain boundary penetration of oxide is evident. Above $1500^{\circ} \mathrm{F}$ the bulk of the oxide grows rapidly, remains adherent and apparently quite dense, but is poorly protective.

According to Rosenberg (1968), the $70 / 30 \mathrm{Ni} / \mathrm{Cu}$ alloy has the best hightemperature strength of the straight nickel-copper alloys. This alloy also has the greatest resistance to creep. Monel Alloy 401 has a low temperature coefficient of electrical resistivity. It is used in the manufacture of wire-wound resistors. Monel Alloy 402 is used for fixtures in operations for pickling steel and copper alloys. It is resistant to hot sulfuric acid pickling solutions and to hydrogen embrittlement when it is galvanically coupled to steel.

In Monel Alloy 403, the nickel, iron, and manganese contents are so adjusted that the alloy remains nonmagnetic at the freezing point of sea water $\left(27^{\circ} \mathrm{F}\right)$. It was developed for use in mine-sweepers. Monel Alloy 404 is characterized by low magnetic permeability and excellent brazing characteristics. Residual elements are controlled at low levels to provide a clean wettable surface even after prolonged firing in wet hydrogen. Its permeability is not significantly affected by processing and fabrication.

Monel Alloy R-405 is very similar to Monel Alloy 400 in all respects except that a controlled amount of sulfur is added to improve machining characteristics. Monel Alloy 
406 is particularly resistant to corrosion from mineral waters. Monel Alloy 474 is essentially free from nonmetallic inclusions, is nonmagnetic, and has low permeability. The alloy has good formability and superior brazing characteristics even in wet hydrogen atmospheres.

Monel Alloy K-500 has good mechanical properties over a wide temperature range (strength, ductility, and toughness). Monel Alloy 501 is similar to Alloy K-500, except that it has improved machining characteristics.

\section{Oxidation and Atmospheric Corrosion}

According to a summary of the corrosion resistance of nickel base alloys included in the ASM International Handbook of Corrosion Data (1989), corrosion of Monel is negligible in all types of atmospheres, although a patina will develop. Incoloy Alloy 825 develops a very thin and protective, passive oxide film that prevents even significant tarnishing. Mirror finishes on Incoloy Alloy 825 surfaces can be maintained after extended exposure to the atmosphere.

A 20 year atmospheric corrosion testing program evaluating the corrosion performance of non-ferrous metals and alloys has been completed by the American Society for Testing and Materials (ASTM) (Copson, 1955). Samples of Monel were exposed independently at Bayonne, New Jersey, and the results of these exposures were also considered. The testing program completed by ASTM consisted of 24 non-ferrous metals boldly exposed vertically at seven test locations. The testing at Bayonne, New Jersey, provided three conditions of exposure. These were sheltered vertical, exposed vertical, and exposed inclined. The results of these testing programs were reported by Copson (1955). Data for the Monel test specimens for ASTM tests can be found in Table 2 and for Bayonne exposures in Table 3. Results of the Monel exposures are summarized as follows.

In the ASTM testing program, Monel was exposed to seven environments (see Table 2). The locations are Altoona, Pennsylvania, New York, New York, Sandy Hook, New Jersey, Key West, Florida, La Jolla, California, State College, Pennsylvania, and 
Phoenix, Arizona. The Altoona and New York sites are industrial locations with severe air pollution. The Sandy Hook site is an industrial marine location. Key West proved to be a comparatively mild marine location. La Jolla is a severe marine location. State College and Phoenix are rural locations, with Phoenix being quite dry. Monel was found to be quite resistant to general corrosion in marine and rural locations. At Sandy Hook, the corrosion rate of Monel increased to more than three times the corrosion rates of any of the rural or marine locations. The severe industrial locations of New York and Altoona proved to be the most corrosive environments to Monel, providing more than two times the general corrosion rate found at the industrial marine location of Sandy Hook.

Monel samples exposed to the sheltered vertical condition at Bayonne, New Jersey exhibited higher corrosion rates than those boldly exposed to the atmosphere (see Table 3). Also, Monel sheets exposed in the sheltered vertical position showed deeper pits than those boldly exposed in a vertical position. Inclined samples that were boldly exposed corroded at a lower rate than the sheltered vertical samples but at a higher rate than the boldly exposed vertical samples. The deleterious effects of sheltered exposures versus boldly exposed tests are well documented in the literature (Vinson, et al., 1995).

Southwell, et al. (1976) reported on the results of 16-year tests of materials exposed in coastal and inland atmospheres in a tropical environment. Data for atmospheric corrosion of Monel and for comparison metals are included in Table 4 and are summarized in Figures 1 and 2 for inland and coastal atmospheric exposure, respectively. Of the fifty-two different alloys included in this study, Monel (cold-rolled and hot-rolled) is of interest in this study. For comparison, data for a 70Cu-30Ni alloy, for Type 316 stainless steel, and for a structural carbon steel $(0.25 \mathrm{C}-0.08 \mathrm{Cu})$ are reported.

For atmospheric corrosion due to exposure in a tropical environment, the data suggest that the Monel alloy is superior to the $70 \mathrm{Cu}-30 \mathrm{Ni}$ alloy for exposures longer than 8 years and to the carbon steel specimens for all measurements (see Table 4). The Monel alloy lost approximately one half as much mass due to corrosion as did the $70 \mathrm{Cu}-30 \mathrm{Ni}$ alloy after eight and sixteen year exposures. The Monel alloy showed less than three percent of the mass loss realized by the carbon steel at all times. The Type 316 stainless steel had the best overall corrosion resistance, having zero mass loss over the duration of 
the atmospheric exposure. It is worth noting that, with the exception of carbon steel, each of these metals exhibited some resistance to pitting. The pitting penetration of these metals was reported as being less than 5 mils.

Baker (1988) summarized the results of exposures in the natural marine atmosphere at Kure Beach, North Carolina, for a test duration of 45 years for some nickel base alloys (Incoloy Alloy 825 was exposed for only 28 years). Baker found that Monel Alloy 400, Monel Alloy K500, Nickel Alloy 200, and Incoloy Alloy 825 all exhibited longterm corrosion resistance to the marine atmosphere. Corrosion rates for these alloys were less than $1 \mu \mathrm{m} / \mathrm{year}$ after their respective test durations. This study found that the nickelbase alloys generated a very thin oxide film that provided excellent resistance to corrosion. One test panel from Monel Alloy 400, Monel Alloy K500, and Nickel Alloy 200 was evaluated after 36 years. Baker reported corrosion rates of $0.3 \mu \mathrm{m} / \mathrm{year}$, and a pit depth of $0.1 \mathrm{~mm}$ for the Monel Alloy 400 specimen. Monel Alloy K500 showed a corrosion rate of $0.2 \mu \mathrm{m} /$ year and a pit depth of $0.2 \mathrm{~mm}$, maximum. A corrosion rate of $0.25 \mu \mathrm{m} / \mathrm{year}$ and no pitting was found on the Nickel Alloy 200 specimen.

In a review of selected literature on the corrosion of metal in marine environments, Boyd and Fink (1975) state that Monel Alloy 400 and the cupro-nickels are all resistant to marine environments. The investigators report that Incoloy Alloy 825, Monel Alloy 400 and Monel Alloy K500 are resistant to marine environments, but may develop some pits at sites where sea water is stagnant. Hastelloy Alloy G (45Ni-21Cr-7Mo-20Fe-2Cu-2.5Co) was reported to have negligible crevice attack and good resistance to general attack in sea water. Further, Monel Alloy 400 was found to be susceptible to oxygen concentrationcell corrosion. Thus, this study suggests that crevices and other areas where sea-salt solutions may be trapped and set up local cells be avoided when using Alloy 400 in marine environments. It was noted that Incoloy Alloy 825, Monel Alloy 400, and Monel Alloy $\mathrm{K} 500$ exposed to a splash zone maintain passive surfaces due to the frequent splashing and well-aerated conditions as long as the surface is clean and free of deposits and pockets where sea water can collect. 
In a series of atmospheric corrosion tests carried out in Birmingham, Alabama, eleven stainless steels and thirteen nickel alloys were exposed over a 10 year period (Evans, 1972). Compositions of the nickel alloys included in the tests are listed in Table 6.

Upon inspection of the samples after exposure, Evans (1972) noted that Alloy 600 and Alloy DS suffered the least attack with weight losses in the range 2 to $6 \mathrm{mg} / \mathrm{cm}^{2}$ and that the corrosion was mainly confined to shallow pitting beneath a continuous, thin film of corrosion product. Nickel Alloy 200 and Nickel Alloy 213 suffered more corrosion with weight losses of 50 to $60 \mathrm{mg} / \mathrm{cm}^{2}$. These nickel alloys also exhibited shallow pitting beneath a thin film of corrosion product. Alloy 301 gave lower weight losses than Nickel Alloy 200 , ca $20 \mathrm{mg} / \mathrm{cm}^{2}$, but did not pit. The nickel-copper alloys, Monel Alloy 400 and Monel Alloy K500, exhibited weight losses similar to Alloy 301, but showed more extensive and deeper pitting, especially on the more sheltered, downward-facing samples. The cupro-nickels were inferior to the Monel alloys, exhibiting no pitting, but higher corrosion weight losses of 30 to $50 \mathrm{mg} / \mathrm{cm}^{2}$ were observed.

The 1957 Test Program carried out by the American Society for Testing and Materials (ASTM 1959; 1961; 1962; 1966) included five nickel base alloys, Nickel Alloy 200, Incoloy Alloy 800, Inconel Alloy 600, Monel Alloy 400, and Incoloy Alloy 825, exposed to the atmosphere of four test sites. Compositions of these alloys are included in Table 7. Data summarizing the results of the test program through 7 years exposure may be found in Table 8. Actual 7-year exposure times varied at the three locations involved. Exposure times are listed in Table 9. Seven-year specimens at Port Reyes, California were vandalized so that no 7-year data is available from this test site. Included in this summary, however, is two year data for all four test sites including Kure Beach (25 meter lot), North Carolina, Newark, New Jersey, State Park, Pennsylvania, and the Port Reyes site.

Data from the 1957 Test Program were investigated by van Rooyen and Copson (1968). In this study, the nickel-chromium-iron alloy, Incoloy Alloy 825, showed lowest corrosion rates after both exposure times, while panels of Monel Alloy 400 and Nickel Alloy 200 were corroded more. Pit depths of all alloys considered were very small, all being less than 1 mil deep. The Incoloy alloys and the Inconel Alloy 600 exhibited marked decreases in corrosion rates at all sites between two- and seven-year measurements. The 
Nickel Alloy 200 and the Monel Alloy 400 corroded at a nearly linear rate with time through 7 years.

The investigators make reference to previous work done by Wesley (1940) which they feel is consistent with the findings from the 1957 program data. This study also mentions measurements of the thickness of Monel Alloy 400 roofing sheets on the old Penn Station in New York City. After some 54 years, when the building was torn down, the sheets were measured. The sheets measured roughly 0.017 inches thick compared to an initial thickness of about 0.020 inches. This corresponds to a corrosion rate of 0.342 milligrams per square decimeter per day (mdd), which is in close agreement with New York City exposure data from the ASTM test program reported previously by Copson (1955). Copson found corrosion rates for Monel Alloy 400 to be 0.35 and 0.38 mdd for 10-year and 20-year exposure, respectively (see Table 2).

\section{Aqueous Corrosion}

Southwell, et al. (1976) reported on the results of 16-year tests of materials exposed to sea and fresh water immersion and sea water mean tide in a tropical environment. Data for aqueous corrosion of Monel and for comparison metals are included in Table 5 and are summarized in Figures 3, 4, and 5 for sea water immersion, fresh water immersion, and sea water mean tide exposure, respectively. As was found in the atmospheric exposure data, carbon steel exhibited the worst corrosion resistance of the metals considered in this report. The Monel alloy showed less corrosion resistance than the $70 \mathrm{Cu}-30 \mathrm{Ni}$ alloy and the stainless steel. Monel displayed a susceptibility to pitting in all aqueous corrosion environments, although the cold rolled Monel showed slightly more resistance than the hot rolled version. Both Monels, however, pitted more than the $70 \mathrm{Cu}$ $30 \mathrm{Ni}$ alloy, which was more resistant than the stainless steel to pits.

In reviewing the results of the Southwell and Alexander data (1969), Boyd and Fink (1975) report that the nickel-copper alloys (Monel) and nickel-chromium-iron alloys (Incoloy Alloy 825) will become covered with marine fouling in the tide zone and below making passivity difficult to maintain. Table 5 summarizes the behavior of Monel Alloy 
400 immersed in fresh water, immersed in sea water, and at mean tide level in the tropical environment of the Panama Canal Zone.

After 16 years exposure, Monel Alloy 400 (cold-rolled) showed a weight loss penetration of 0.17 mpy with a maximum pit depth of 21 mils. The investigators state that general experience indicates that the pit depth on Monel Alloy 400 rarely exceeds 50 mils in the tide zone. Further, they state that pits develop slowly and do not increase appreciably in depth after the eighth year. Cupro-nickels reportedly are more resistant in this environment and tend to show only slight pitting in the same exposures.

In a review of selected literature on the corrosion of metal in marine environments, Boyd and Fink (1975) found that in submerged high velocity applications, the nickelcopper alloys, as represented by Monel Alloy 400 and Monel Alloy K500, have excellent resistance to sea water. Their surfaces maintain passivity, and water motion tends to prevent fouling. Data provided by The Intemational Nickel Company for high velocity sea water impingement test show corrosion rates of $0.3 \mathrm{mpy}, 0.4 \mathrm{mpy}$, and $0.4 \mathrm{mpy}$, respectively, for Incoloy Alloy 825, Monel Alloy 400, and Monel Alloy K500. This test lasted for 30 days with a flow velocity of $135 \mathrm{fps}$. A cast iron and a medium-carbon steel were included in this test. The iron base alloys were greatly inferior to the nickel base alloys, exhibiting corrosion rates of $176 \mathrm{mpy}$ and $600 \mathrm{mpy}$, respectively, for the mediumcarbon steel and the cast iron.

In quiet sea water, Monel Alloy 400, Monel Alloy K500, and similar alloys tend to pit or to experience local attack at screened area (Boyd and Fink, 1975). This is supported by data in Table 5 , which shows a weight-loss penetration of only 8.70 and 8.40 mils after 16 years but pits of up to 55 and 82 mils for cold-rolled and hot-rolled Monel panels, respectively. Boyd and Fink (1975) state that pitting of the copper-nickel alloys tends to progress rapidly during the first year, after which the pits tend to spread out rather than deepen.

Data for corrosion rates and depth of attack on Monel Alloy 400, Monel Alloy K500, and Incoloy Alloy 825 specimens exposed for 3 years in quiet sea water can be found in Table 10. The data show that Monel Alloy 400 and Monel Alloy K500 corrode at nearly equal rates with similar pit depths, ranging from 30 to 55 mils. The Monel alloys 
experience numerous broad pits. Incoloy Alloy 825 shows greatly improved corrosion resistance. The weight loss of the alloy was found to be less than one percent of the weight loss experienced by either of the Monel alloys during the testing period. Further, Incoloy Alloy 825 had very shallow pit depths, ranging from 1 to 7 mils, but exhibited crevice corrosion beneath bamacles.

In testing the effect of material composition in high-temperature water corrosion, Roebuck (1955) reported on the general corrosion resistance of a carbon steel, a 70Cu$30 \mathrm{Ni}$ alloy, a Hastelloy alloy, and a Monel alloy exposed to water with a dissolved oxygen concentration of about $1 \mathrm{ml}$ per liter at high temperatures. The testing temperatures ranged from $93^{\circ} \mathrm{C}$ to $360^{\circ} \mathrm{C}$. Roebuck categorized corrosion resistance by assigning grades of $\mathrm{A}, \mathrm{B}$, or $\mathrm{C}$, to each metal at each intermediate temperature. The grades were assigned based on the following:

A) Highest Resistance: No apparent corrosion products; clean tarnish film. Less than 0.3 milligrams per square centimeter per month, or 1 milligram per square decimeter per day.

B) Intermediate Resistance:

No apparent corrosion products; clean tarnish film. Greater than 0.3 milligrams per square centimeter per month.

or

Some apparent corrosion products on surface or moderate amount of pitting and spalling. Less than 0.3 milligrams per square centimeter per month.

C) Low Resistance: Heavy deposit of corrosion products on surface, or general deep pitting and spalling. Greater than 0.3 milligrams per square centimeter per month.

Roebuck found that of the four metals listed above, the carbon steel and the Hastelloy alloy showed the least resistance to general corrosion in water. From $93{ }^{\circ} \mathrm{C}$ to $260^{\circ} \mathrm{C}$, Roebuck assigned a grade of $\mathrm{B}$ and a grade of $\mathrm{C}$ for temperatures ranging from $316^{\circ} \mathrm{C}$ to $360^{\circ} \mathrm{C}$ for the carbon steel. The Hastelloy alloy was assigned a grade of $\mathrm{A}$ at $93^{\circ} \mathrm{C}$, a grade of $\mathrm{B}$ at $149^{\circ} \mathrm{C}$, and a grade of $\mathrm{C}$ for temperatures ranging from $205^{\circ} \mathrm{C}$ to $360^{\circ} \mathrm{C}$. Both the $70 \mathrm{Cu}-30 \mathrm{Ni}$ alloy and the Monel alloy received grades of $\mathrm{A}$ for temperatures from $93{ }^{\circ} \mathrm{C}$ to $260^{\circ} \mathrm{C}$, but the Monel alloy showed superior corrosion 
resistance at $316^{\circ} \mathrm{C}$ receiving a grade of $\mathrm{B}$ while the $70 \mathrm{Cu}-30 \mathrm{Ni}$ alloy received a $\mathrm{C}$. Both alloys received a grade of $\mathrm{C}$ at $360^{\circ} \mathrm{C}$.

Jet impingement tests were carried out by the method described by May and DeVere Stackpoole to assess corrosion in moving sea-water (White, et al., 1966). These tests were carried out in the waters of the Mediterranean and the Dead Seas. Typical analysis of Mediterranean sea water and of water from the Dead Sea as used by White, et al. (1966) are given in Table 11. Among the materials tested were Cupro-nickel 70/30, Monel, an 18:8 stainless steel ( $7 \mathrm{Ni}-17.6 \mathrm{Cr}$ ), and a mild steel (0.27Mn-0.11C). The 70/30 Cupro-nickel was included in all runs as reference standards. Data for the jet impingement tests are summarized in Figure 6. In addition to the jet impingement tests, static immersion tests were carried out by the investigators. Data for materials relevant to this survey are included in Tables 12,13, and 14.

Results of the impingement tests and the total immersion test show that the stainless steel is superior to Monel, which was more resistant than the 70/30 cupro-nickel in all test conditions. Partial immersion test data, however, show that Monel is more resistant to the static sea water of the Dead Sea, while less resistant to the static sea water of the Mediterranean Sea. Both the stainless steel and Monel were greatly superior to the mild steel in all tests.

Eight materials were commonly used for engineering applications in the marine environment were exposed to chlorinated and unchlorinated sea-water under quiescent and flowing conditions for one year by Thomas, et al. (1988). The researchers suggested that the term "halogenation" be used to more accurately characterize the electrolytic addition of chlorine to sea-water. This convention will be used in this survey in a summary of their findings.

Thomas, et al. (1988) exposed engineering materials to natural sea water and halogenated sea water at concentrations of 1 and $4 \mathrm{mg} / \mathrm{L}$ for approximately one year (8900 hours). Materials of interest included in the study were a 70/30 Cupro-nickel, Monel Alloy 400, and Monel Alloy K500. The researchers found that the 70/30 Cupronickel and the K-Monel showed no differences between exposure in unhalogenated sea water and the $1 \mathrm{mg} / \mathrm{L}$ treatment, but a 300 percent increase corrosion rate was observed in 
the $4 \mathrm{mg} / \mathrm{L}$ treatment. The Monel Alloy 400 samples showed an increased resistance to corrosion at $1 \mathrm{mg} / \mathrm{L}$ and no difference between the unhalogenated sea water and the 4 $\mathrm{mg} / \mathrm{L}$ treatment.

Upon visual inspection of the coupon surfaces, the investigators noted that the Cupro-nickel showed some localized corrosion, especially at the edges and in crevices, and the extent of localized corrosion increased at both levels of halogenation. The Monel alloys exhibited pitting and showed edge and crevice corrosion at all conditions. The Monel Alloy K500 was affected by both levels of halogenation, while the Monel Alloy 400 showed a reduction in localized corrosion with halogenation.

Wheatfall (1967) reported on the corrosion of metals in deep ocean environments. Test specimens for general corrosion experiments in deep ocean environments, including AISI Type 304 stainless steel, 70/30 cupro-nickel, Monel Alloy 400, Monel Alloy K500, and Incoloy Alloy 825, were exposed at 5640 feet for 123 days and 751 days and at a depth just below the water surface for 386 days. Data for Type 304 stainless steel and $70 / 30$ cupro-nickel at 5300 feet for 1064 days are also included. Rectangular metal plates (12 $\times 12$ inches) were used in three deep-marine exposures. The samples were from 1/16 to $1 / 4$ inches thick. The surface exposure samples were $12 \times 3$ inches and $1 / 16$ inches thick. In all of these tests, a crevice of constant area existed on each specimen due to the contact area created by nonmetallic supporting fixtures. In addition, crevice corrosion experiments were carried out on specimens of Type 304 stainless steel $(12 \times 2 \times 1 / 8$ inches) and Monel Alloy 400 ( $12 \times 2 \times 1 / 16$ inches). The crevice area was varied from 0 to 14 square inches on both faces of the specimens by means of tree-shaped nylon strips. The crevice corrosion samples had an additional 8 square inch crevice on each face of the alloy due to nylon strips used to secure samples to the steel rack. Data from the general corrosion experiments can be found in Table 15 and is summarized as follows.

Wheatfall (1967) found that, of the alloys considered in this survey, only the $30 \%$ cupro-nickel alloy showed a resistance to localized corrosion, but the general corrosion rates for this alloy were among the highest. Only the stainless steel exhibited higher general corrosion rates. The stainless steel also realized the susceptibility to localized corrosion. Incoloy Alloy 825 exhibited the greatest overall resistance to general 
corrosion, but suffered severe pitting in the crevice created by the nylon strip used to secure the samples. Monel Alloy 400 was more resistant to corrosion in all test conditions than was Monel Alloy K500, but both Monel alloys suffered from localized corrosion inside and outside the crevice area.

The crevice corrosion experiments included Monel Alloy 400 and Type 304 stainless steel. Wheatfall found moderate crevice corrosion on Type 304 stainless steel at a depth of $2340 \mathrm{ft}$, but no attack was observed on Monel Alloy 400. No localized corrosion was detected on the boldly exposed surfaces of either material. In $6780 \mathrm{ft}$ of water, more severe deterioration was noted for both alloys. Incipient crevice corrosion was evident on Monel Alloy 400, but no pits were present. Wheatfall attributes the increase in corrosion at this depth to an increase in oxygen content from $0.70 \mathrm{ppm}$ to 1.60 ppm as well as to a longer exposure time. Severe crevice corrosion and overall surface corrosion were quite pronounced in the shallow water investigation. Several perforations at the crevices and on the surfaces remote from the crevices were found on the stainless steel in the shallow water exposures. One of the Monel Alloy 400 samples was perforated at the crevice under these conditions. Wheatfall concluded that variations in oxygen content in the crevice-corrosion experiments was the most important factor in the behavior of Type 304 stainless steel and Monel Alloy 400.

Cramer, et al. (1983) reported on results of corrosion tests conducted in brine steam process streams produced by flash evaporation of wellhead brine from geothermal well Magmamax No. 1 at the Bureau of Mines geothermal test facility. Operating conditions for test packages averaged over the approximately 45 days of the study are given in Table 16. Figure 7 shows a block diagram of the facility and relative locations of the test packages for the corrosion tests. General and localized corrosion rates were gathered for nickel alloys including Nickel Alloy 201, Monel Alloy 400, Monel Alloy 404, Incoloy Alloy 825, and Hastelloy Alloy $G$ after 15, 30, and 45 days exposure in brine and steam. The material composition of these alloys are given in Table 17. Data for general corrosion measurements are reported in Table 18 and are summarized in Figure 8.

The data show that Nickel Alloy 201 corrodes at substantially higher rates than the nickel alloys in brine and steam environments. Corrosion rates for Incoloy Alloy 825 in 
the brine and steam environments were negligible when compared to those of the Monel alloys. Of the alloys considered, the Hastelloy Alloy $G$ showed the greatest resistance to general corrosion. Monel 404 corroded more rapidly than Monel Alloy 400 in all separated steam environments. Highest corrosion rates were experienced in wellhead brine. Corrosion rates decreased with time for all nickel base alloys. The investigators suggest that much of the corrosion in the brine and steam environments occurred in the first 15 days and that the scale and corrosion product was protective, substantially retarding further corrosion. Investigators report that with the exception of Hastelloy Alloy $\mathrm{G}$, which exhibited negligible corrosion, corrosion rates typically decreased with increasing exposure time for all of the alloys.

Cramer, et al. (1983) recorded maximum and average pit penetrations for nickel alloys including Monel Alloy 400, Monel Alloy 404, and Incoloy Alloy 825. Data collected is listed in Table 19 and are summarized in Figure 9. Average pitting rates for the Monel alloys varied from 260 to $430 \mu \mathrm{m} /$ day in 45 -day tests in the brine environments. Average pitting rates for the Monel alloys varied from 210 to $330 \mu \mathrm{m} /$ day in 45 -day tests in the steam environments. Very few pits were observed for Monel Alloy 400 and for Monel Alloy 404 in the wellhead brine. All alloys considered pitted at substantial rates in the steam environments. Monel Alloy 400 and the Hastelloy Alloy G showed more resistance to pitting in the steam environments than the other two alloys, with Hastelloy Alloy $\mathrm{G}$ showing greater resistance after the 15 day exposures. Pitting rates of all alloys decreased significantly between 15-day and 30-day exposures.

Investigators found no stress corrosion cracking in either Monel alloys and Hastelloy Alloy G. Incoloy Alloy 825 was found to crack in wellhead brine. The Monel alloys exhibited severe uneven local corrosion in wellhead brine. Investigators found crevice corrosion in Incoloy Alloy 825 in the brine and steam environments PI through P4. The Monel alloys exhibited no crevice corrosion in steam environments, but experienced slight crevice corrosion in the brine environment $\mathrm{P} 2$.

In a review of selected literature on corrosion of metals in marine environments, Boyd and Fink (1978) gathered data on corrosion of metals in sea water brine. Corrosion data for metals in normal sea water and sea water brine at cold and elevated temperatures 
show that, in cold sea water $\left(80^{\circ} \mathrm{F}, 8.2 \mathrm{pH}, 8.5 \mathrm{ppm}\right.$ oxygen, salinity $\left.=35 \mathrm{~g} / \mathrm{L}\right)$, Monel exhibits a low corrosion rate $(0.0003$ inches per year (ipy)). In cold sea water, carbon steel, a 70/30 copper-nickel alloy, and Type 304 stainless steel corroded at rates of 0.029 ipy, $0.0015 \mathrm{ipy}$, and $0.0030 \mathrm{ipy}$, respectively. In hot sea water $\left(187^{\circ} \mathrm{F}, 8.2,7.8 \mathrm{ppm}\right.$ oxygen, salinity $=59.3 \mathrm{~g} / \mathrm{L}$ ) Monel corroded four times faster than Type 304 stainless steel (0.0004 ipy for Monel compared to 0.0001 ipy for stainless steel). The 70/30 copper-nickel alloy corroded more than 3 times faster than Monel and carbon steel corroded nearly 60 times faster than Monel. Of the alloys considered here, only Monel Alloy 400 showed an increased corrosion rate as the sea water temperature increased.

Results of corrosion tests in San Diego in deaerated sea water brine after 90 days show than Incoloy Alloy 825 is superior to Monel Alloy 400 in resistance to general corrosion (Boyd and Fink, 1978). Incoloy Alloy 825 exhibits crevice corrosion in all tests conditions, while Monel seemed to be immune to crevice attack. Type 316 stainless steel was superior to Monel Alloy 400 but exhibited more crevice attack than Incoloy Alloy 825. Monel Alloy 400 was, however, more resistant than a 70/30 copper-nickel, which was greatly superior to carbon steel.

In a report on the corrosion of metals in marine environments (Beavers, et al., 1986), it is reported that Monel Alloy 400 reaches a maximum weight loss in sea water at $30^{\circ} \mathrm{C}$, and the weight loss drops to very low values at $50^{\circ} \mathrm{C}$; whereas, in the same exposure, pit depths were reported to be greatest at $18^{\circ} \mathrm{C}$, decreasing to negligible values at $50^{\circ} \mathrm{C}$. Hastelloy Alloy $\mathrm{G}$ is reported to reach a maximum depth of crevice attack at 28 ${ }^{\circ} \mathrm{C}$. In 30-day tests, it is reported that Hastelloy Alloy $\mathrm{G}$ exhibited an average crevice attack of $0.03 \mathrm{~mm}$ at $12{ }^{\circ} \mathrm{C}, 0.05 \mathrm{~mm}$ at $28^{\circ} \mathrm{C}$, and $0.0 \mathrm{~mm}$ at $50^{\circ} \mathrm{C}$. No crevice corrosion was observed after 31 weeks' exposure at $25^{\circ} \mathrm{C}$ and $60^{\circ} \mathrm{C}$ in Incoloy Alloy 825 , but crevice corrosion was observed after 20 weeks' exposure at $100^{\circ} \mathrm{C}$.

\section{Galvanic Corrosion}

Pelensky, et al. (1978) reported on the progress of investigations being conducted at Panama Canal Zone, relative to the corrosion of dissimilar metal couples exposed in the 
atmosphere, in the soil, and in sea water. Alloys included in the study were 6061-T6 and 7075-T6 aluminum, 360 brass, AZ31 magnesium, Monel Alloy 400, 4340 steel, Type 316 stainless steel and titanium 6A1-4V. Total (general, galvanic, crevice) corrosion rates, in $\mathrm{mm} /$ year, are given in Tables 20,21, and 22, respectively, for atmospheric, soil, and aqueous exposures. The corrosion rates shown are of the alloy indicated, when coupled with various dissimilar metals. For comparison, the similar metal average corrosion rate is also indicated.

Atmospheric specimens used in the study were flat rectangular plates 0.55 by 2.54 by 3.81 centimeters. The plates were coupled using a stainless steel machine screw insulated from the faces of the specimens. These tests were carried out at the open field site at Fort Sherman, Panama Canal Zone. Atmospheric data for the 4340 steel indicates a high initial corrosion rate decreasing with exposure time, and a tendency toward leveling off after 8 months exposure (see Table 20). The greatest corrosion rates were observed when the 4340 steel is coupled with stainless steel and with Monel Alloy 400 . The corrosion rates for Monel Alloy 400 and 316 stainless steel were essentially zero for all couples. Coupling of AZ31 magnesium with steel, stainless steel, and Monel resulted in the greatest attack on magnesium.

Soil and aqueous test specimens were 2.54 centimeters in diameter and 1.27 centimeter long. They were coupled using a steel screw but were separated by a plexiglass rod. The soil specimens were installed at the water table, buried at a depth of 1.2 meters below the soil surface, in an area adjacent to the open field test site. Investigators report that the 4340 steel shows a tendency toward slightly increased attack when coupled with brass and Monel and somewhat less when coupled with 6061-T6 aluminum (see Table 21). Appreciable sacrificial protection is indicated when coupled with magnesium. Corrosion rates of Type 316 stainless steel and Monel Alloy 400 when exposed in soil are considered slight or negligible.

Aqueous test specimens were completely immersed approximately 1.4 meters below the water surface at low tide and approximately 1.7 meters below the surface at high tide. They were exposed in Manzanillo Bay at the Coco Solo Naval Station, Panama Canal Zone. The Type 316 stainless steel exhibited crevice and pitting attack in the 
stainless steel couple and in the dissimilar couple with Monel Alloy 400 (see Table 22). There was no evidence of corrosion when coupled with other dissimilar metals. Investigators noted that in some instances when stainless steel is coupled with Monel Alloy 400 , that the stainless steel is not attacked, but Monel is attacked.

Analysis of 4340 steel found that increased attack in sea water when coupled with austenitic stainless steel, brass, Monel, and titanium alloys. The 4340 steel is protected by coupling with magnesium and aluminum alloys. The Monel Alloy 400 is protected when coupled with magnesium, steel, aluminum, and brass alloys; however, pitting of Monel occurs when coupled with titanium and also in similar Monel-Monel couple, as well as in some instances with austenitic stainless steel. Investigators rated the extent of attack in sea water from greatest to least as follows: magnesium alloy, steel, brass, austenitic stainless steel, aluminum alloys, Monel, and titanium. No attack on titanium was observed under any test conditions.

Southwell and Alexander (1969) reported on 16-year exposure data for bimetallic couples exposed to various waters and to various atmospheres at Panama Canal Zone. Results for corrosion penetration of the strip metal and the plate metal of galvanic couples exposed to aqueous environments are reported in Tables 23 and 24, respectively. In sea water, it was found than carbon steel is a highly effective anode for protecting Type 316 stainless steel, Nickel, Monel Alloy 400, and the 70/30 copper-nickel alloy. At mean tide, a high degree of anode protection was evident throughout the first 8 years. In all three aqueous environments, the Monel-bronze couple developed more severe galvanic corrosion than did the more noble 18:8 stainless steel-bronze couple. No significant protection of Monel was observed in fresh water and only to a slight degree at mean tide. In sea water, successful protection of Monel with bronze was achieved in about $50 \%$ of the specimens. Investigators concluded that in order to obtain effective cathodic protection of the nickel alloys, a higher potential will be needed than that supplied by anodes of bronze and copper. Data reveals that using a carbon steel anode on 70/30 copper-nickel plates resulted in almost complete protection of the copper-nickel alloy through eight years exposure, at the end of which, the steel anodes were depleted and corrosion of copper-nickel proceeded at its normal, uncoupled rate. Monel plates were 
equally protected, and the anodes lasted for more than eight years. Investigators found that during the relatively long life of the anodes, highly effective protection was afforded the two nickel alloys. Weight loss was insignificant, and no crevice corrosion or underfouling corrosion was detected. Panels were entirely free of pitting during the protected period.

Results of galvanic couples exposed to atmospheric sites are reported in Table 25. A summary of the observations of Southwell, et al. (1976) follows. Two of the most noble metals in the atmospheric exposures, Type 316 stainless steel and Monel Alloy 400, reacted differently than when in sea water in which Monel caused slightly greater corrosion of more anodic metals. In the atmospheric exposures, Type 316 stainless steel caused a greater amount of anodic corrosion of steel than any other noble metal; almost double the amount caused by Monel cathodes. Investigators report that the extremely noble position of Type 316 stainless steel and the nickel-copper alloys in the galvanic series sometimes makes these materials hazardous for use in unfavorable area ratios with almost any other constructional metallic alloy. When used in structures, these metals are galvanically protected and can survive undamaged for years.

Southwell, et al. (1976) derived the following conclusions on the galvanic corrosion of metals in various environments. Carbon steel was a very effective anode for more noble metals. Strips of steel effectively protected bronzes, Monels, and austenitic stainless steels for periods in excess of 8 years in sea water, and through 16 years at mean tide. In fresh water, cathodic protection was not very effective. However, when the anodes were smaller than the cathodes, the anodes were significantly damaged by galvanic action in this medium. In the atmospheric exposures, the coastal marine atmosphere caused four to eight times more galvanic corrosion than the inland atmosphere.

\section{Stress Corrosion Cracking}

An important consideration in the use of Monel Alloy 400 in corrosive environments is its general freedom from stress corrosion cracking. The limiting 
temperatures for use of Monel Alloy 400 in various environments, according to Mudge (1948), are given in Table 26.

After 24 years of exposure at Kure Beach, North Carolina, Baker (1988) found that Monel Alloy K-500 continued to resist stress corrosion cracking. The test included a welded and a non-welded sample submitted to a two-point loaded bent beam stress corrosion test exposed for six months in sea water and then re-exposed in the marine atmosphere, 25 meters from the ocean. A stress of $96 \mathrm{ksi}$ was introduced to the Monel alloy for the duration of the test. Some Monel Alloy K500 samples (welded and not welded) were tested for stress corrosion cracking after exposure to low velocity $(5 \mathrm{~m} / \mathrm{s})$ sea water. Analysis of these samples revealed no failure between 548 to 964 day exposures.

Copson and Cheng (1956) reported the results of U-bend tests investigating the susceptibility of Monel to stress corrosion cracking when exposed to hydrofluoric acid vapor. In addition to Monel Alloy K500 and Monel Alloy 400, a special Monel containing 1 percent silicon and a high nickel Monel containing 85\% nickel and 15\% copper were included in the tests. Investigators found the Monel Alloy K500 to quickly develop a large number of closely spaced transcrystalline cracks penetrating deeply from the tension side of the U-bend. Reportedly, hot-rolled and age-hardened material behaved similarly. Monel Alloy 400 was found to crack in much the same manner as Monel Alloy K500. Cold-rolled material showed transcrystalline cracking, while annealed material exhibited cracking that was predominantly intergranular, with many short transcrystalline branches. Copson and Cheng report that in many instances, the cracks seemed to stop growing or to turn in a lengthwise direction after penetrating about half way through the specimens. The Monel plus 1 percent silicon behaved similarly to Monel Alloy 400, and the high nickel Monel cracked profusely. Investigators concluded that alloy additions of silicon, nickel, and aluminum to Monel have no major influence on susceptibility to cracking.

Copson and Cheng (1956) totally immersed U-bend specimens of Monel Alloy 400 and Monel Alloy K500 in 48\% hydrofluoric acid, in 30\% hydrofluosilicic acid, and in mixtures of these acids. In conditions where no vigorous aeration was present, corrosion rates were low, and the samples showed no sign of cracking for periods of up to 30 days. 
In conditions where vigorous aeration was present, corrosion was greatly increased. Cracking was found in 15 days on Monel Alloy K500 totally immersed under these conditions. Investigators suggest stress relieving Monel by heating for 1 hour at $1100^{\circ} \mathrm{F}$ to $1200{ }^{\circ} \mathrm{F}$, and they recommend slow cooling.

Kolts and Sridhar (1985) completed a study concerned with the pitting and crevice corrosion resistance of nickel and nickel base alloys, including Hastelloy Alloy G, Hastelloy Alloy G3, and Incoloy Alloy 825. The compositions of the alloys are given in Table 27. Hastelloy Alloy G3 was found to be superior to Incoloy Alloy 825 in stress corrosion cracking resistance in concentrated chloride environments. In dilute chloride solutions, after 1 months' exposure, no localized attack was observed in Hastelloy Alloy $\mathrm{G}$, with a general corrosion rate of less than $0.01 \mathrm{~mm} / \mathrm{yr}$, while Incoloy Alloy 825 exhibited pitting and crevice corrosion and a general corrosion rate of $0.03 \mathrm{~mm} / \mathrm{yr}$. Neither the Hastelloy Alloy $G$ nor the Incoloy Alloy 825 showed any signs of stress corrosion cracking in the dilute chloride solution and the Hastelloy Alloy G3 was not tested in these conditions.

\section{Conclusions}

The general corrosion data for Hastelloy G, Alloy 825, Monel 400 and carbon steel in steam environments suggest that the addition of chromium provides the greatest improvement in materials performance. Chromium-bearing Hastelloy $G$ and Alloy 825 provided the greatest corrosion resistance while the Monel 400 was superior to carbon steel. The performance of the Hastelloy $\mathrm{G}$ was fundamentally the same as Alloy 825 in all environments with the Hastelloy $G$ providing superior pitting resistance in steam environments

From the data identified in the literature, it appears that Alloy 825 provides superior pitting and aqueous corrosion performance when compared to Monel 400 . Galvanic corrosion results are dependent upon the galvanic couple and aqueous media employed in the test. In general, the high-chromium alloys (Alloy 825 and Hastelloy G) are the least susceptible to galvanic corrosion. Monel 400 exhibited exceptional galvanic corrosion resistance in a majority of the corrosion couples, especially when coupled with carbon steel specimens 
A ranking of the overall corrosion performance of the materials investigated in this study from most corrosion resistant to least corrosion resistant is provided below.

1. Alloy 825 and Hastelloy G

2. Monel 400

3. Carbon Steels and Low Alloy Steels

Since the materials to be employed in the Advanced Conceptual Design (ACD) waste package are considered to be somewhat corrosion resistant materials, the Monel alloys should not be precluded as candidates for the outer containment barrier in a wet repository environment. Based upon the corrosion data available for Monel, this material may be suitable for use in a moderately aggressive repository corrosion environment. However, care must be taken to evaluate all potential galvanic effects for specific waste package designs and applications. 


\section{References}

1. "Report of Subcommittee IV on Atmospheric Corrosion: 1957 Test Program - Seven-Year Exposures" Proceedings, American Society for Testing and Materials, Volume 66, 1966, pp. 555-574.

2. "Report of Subcommittee VI on Atmospheric Corrosion: 1957 Test Program," Proceedings, American Society for Testing and Materials, Volume 59, 1959, pp. 176-180.

3. "Report of Subcommittee VI on Atmospheric Corrosion: 1957 Test Program - One-Year Exposures" Proceedings, American Society for Testing and Materials, Volume 61, 1961, pp. 205-214.

4. "Report of Subcommittee VI on Atmospheric Corrosion: 1957 Test Program - Two-Year Exposures" Proceedings, American Society for Testing and Materials, Volume 62, 1962, pp. 216-229.

5. ASM International, Handbook of Corrosion Data, Metals Park, Ohio, 1989.

6. Baker, E. A., "Long-Term Corrosion Behavior of Materials in the Marine Atmosphere," Degradation of Metals in the Atmosphere, ASTM STP 965, S. W.

Dean and T. S. Lee, Eds., American Society for Testing and Materials, Philadelphia, 1988, pp. 125-144.

7. Beavers, J. A., Hock, G. H., and Berry, W. E., Corrosion of Metals in Marine Environments, Metals and Ceramics Information Center, 1986, pp. 5.1 - 5.61.

8. Boyd, W. K. and Fink, F. W., Corrosion of Metals in Marine Environments, Metals and Ceramics Information Center, MCIC-75-245R, May 1975.

9. Boyd, W. K. and Fink, F. W., Corrosion of Metals in Marine Environments, Metals and Ceramics Information Center, MCIC-78-37, March 1978.

10. Buscheck, T.A. and Nitao, J.J. "The Importance of Thermal Loading Conditions to Waste Package Performance at Yucca Mountain," Scientific Basis for Nuclear Waste Management XVII, Materials Research Society, (also Lawrence Livermore National Laboratory Report UCRL-JC-116429, October 1994).

11. Copson, H. R. and Cheng, C. F., "Stress Corrosion Cracking of Monel in Hydrofluoric Acid," Corrosion, National Association of Corrosion Engineers, Volume 12, 1956, pp. 647-653.

12. Copson, H. R., "Atmospheric Corrosion Behavior of Some Nickel Alloys," Symposium on Atmospheric Corrosion of Non-Ferrous Metals, ASTM STP 175, American Society for Testing and Materials, Atlantic City, New Jersey, June 29, 1955, pp. 141-158.

13. Cramer, S. D., Carter, J. P., and Conrad, R. K., "Corrosion and Scaling of Nickel Alloys in Salton Sea Geothermal Environments," Proceedings of the International Symposium on Solving Corrosion and Scaling Problems in Geothermal Systems, NACE, San Francisco, California, 1983, pp. 215-235.

14. Evans, T. E., "Atmospheric Corrosion Behavior of Stainless Steels and Nickel Alloys," Proceedings of the Fourth International Congress on Metallic Corrosion, N. E. Hamner, Ed., NACE, Houston, Texas, 1972, pp. 408-418.

15. Farmer, J.C., R.D. McCright, J.N. Kass, D.B. Bullen, G.E. Gdowski, R.A. Van Konynenburg, M.J. Strum, and H. Weiss, "Survey of Degradation Modes of Candidate Materials for High-Level Radioactive Waste Disposal Containers," Lawrence Livermore National Laboratory Report UCID-21362, Vols. 1-8, June 1988 
16. Gdowski, G.E. "Survey of Degradation Modes of Four Nickel-ChromiumMolybdenum Alloys,' Lawrence Livermore National Laboratory Report UCRLID-108330, March 1991.

17. Kolts, J. and Sridhar, N., "Environmental Embrittlement of Nickel and NickelBase Alloys -- An Analogy to Steels and Austenitic Stainless Steels," Corrosion of Nickel-Base Alloys, American Society for Metals, 1985, pp. 199 -210.

18. Mudge, W. A., "Nickel and Nickel-Copper, Nickel-Manganese, and Related High-Nickel Alloys," The Corrosion Handbook, H. H. Uhlig, Ed., New York, New York, 1948, pp. 675-683.

19. Pelensky, M. A., Jaworski, J. J., and Gallaccio, A., "Corrosion Investigation at Panama Canal Zone," Atmospheric Factors Affecting the Corrosion of Engineering Metals, ASTM STP 646, S. K. Coburn, Ed., American Society for Testing and Materials, 1978, pp. 58-73.

20. Roebuck, A. H., 'Effect of Material Composition in High-Temperature Water Corrosion," Symposium on High-Purity Water Corrosion, ASTM STP 179, American Society for Testing and Materials, Atlantic City, New Jersey, June 28, 1955, pp. 27-34.

21. Rosenberg, S. J., "Nickel and Its Alloys," U. S. National Bureau of Standards Monograph 106, Institute for Materials Research, Washington, D. C., May, 1968, pp. 78-83.

22. Southwell, C. R. and Alexander, A. L., "Corrosion of Metals in Tropical Environments--Nickel and Nickel-Copper Alloys," Materials Protection, Volume 8, Number 3, 1969, pp. 39-44.

23. Southwell, C. R., Bultman, J. D., and Alexander, A. L. "Corrosion of Metals in Tropical Environments--Final Report of 16--Year Exposure," Materials Performance, National Association of Corrosion Engineers, Volume 15, 1976, pp. 9-25.

24. Thomas, E. D., Lucas, K. E., Peterson, M. H., and Christian, D. K., "Effects of Electrolytic Chlorination on Marine Materials," Materials Performance, July 1988. pp. 36-39.

25. U.S. Department of Energy, Office of Civilian Radioactive Waste Management, "Site Characterization Plan, Yucca Mountain Site," DOE/RW-0199, December 1988.

26. Van Konynenburg, R.A., W.G. Halsey, R.D. McCright, W.L. Clarke, Jr., and G.E. Gdowski, "Selection of Candidate Container Materials for the Conceptual Waste Package Design for a Potential High-Level Nuclear Waste Repository at Yucca Mountain," Lawrence Livermore National Laboratory Report UCRL-ID112058 , February 1993.

27. van Rooyen, D. and Copson, H. R., "Atmospheric Corrosion Behavior of Some Nickel Alloys," Metal Corrosion in the Atmosphere, ASTM STP 435, American Society for Testing and Materials, 1968, pp. 175-186.

28. Vinson, D. W., Nutt, W. M., and Bullen, D. B., "Survey of the Degradation Modes of Candidate Materials for High-Level Radioactive Waste Disposal Containers -- Iron-Base, Corrosion-Allowance Materials," final report to Lawrence Livermore National Laboratory: Livermore, California. 1995.

29. Wesley, W. A., "Controlling Factors in Galvanic Corrosion," Proceedings of the Forty-Third Annual ASTM Meeting, American Society for Testing and Materials, Volume 40, 1940, p. 690.

30. Wheatfall, W.L., "Metal Corrosion in Deep Ocean Environments," Naval Engineers Journal, August 1967, pp. 611-613. 
31. White, J. H., Yaniv, A. E., and Schick, H., "The Corrosion of Metals in the water of the Dead Sea," Corrosion Science, Volume 6, 1966. pp. 447-460. 
Table 1. Nominal Compositions of Selected Monel Alloys (Rosenberg, 1968)

\begin{tabular}{|c|c|c|c|c|c|c|c|c|c|}
\hline \multirow[b]{2}{*}{ Designation } & \multicolumn{9}{|c|}{ Nominal chemical composition -- weight percent } \\
\hline & $\mathrm{Ni}$ & $\mathrm{C}$ & $\mathrm{Mn}$ & $\mathrm{Fe}$ & $S$ & $\mathrm{Si}$ & $\mathrm{Cu}$ & $\mathrm{Al}$ & $\mathrm{Ti}$ \\
\hline Monel Alloy 400 & 66.0 & 0.12 & 0.90 & 1.35 & $\overline{0.005}$ & 0.15 & 31.5 & $\ldots$ & $\ldots$ \\
\hline Monel Alloy 401 & 44.5 & 0.03 & 1.70 & 0.20 & 0.005 & 0.01 & 53.0 & $\cdots$ & $\cdots$ \\
\hline Monel Alloy 402 & 58.0 & 0.12 & 0.90 & 1.20 & 0.005 & 0.10 & 40.0 & $\ldots$ & $\ldots$ \\
\hline Monel Alloy 403 & 57.5 & 0.12 & 1.80 & 0.50 & 0.005 & 0.25 & 40.0 & & $\ldots$ \\
\hline Monel Alloy 404 & 55.0 & 0.06 & 0.01 & 0.05 & 0.005 & 0.02 & 44.0 & 0.02 & $\ldots$ \\
\hline Monel Alloy R-405 & 66.0 & 0.18 & 0.90 & 1.35 & 0.050 & 0.15 & 31.5 & .. & $\ldots$ \\
\hline Monel Alloy 406 & 84.0 & 0.12 & 0.90 & 1.35 & 0.005 & 0.15 & 13.0 & $\ldots$ & $\ldots$ \\
\hline Monel Alloy 474 & 54.0 & 0.01 & trace & 0.01 & 0.001 & $<0.01$ & 46.0 & trace & .. \\
\hline Monel Alloy K-500 & 65.0 & 0.15 & 0.60 & 1.00 & 0.005 & 0.15 & 29.5 & 2.80 & 0.50 \\
\hline Monel Alloy 501 & 65.0 & 0.23 & 0.60 & 1.00 & 0.005 & 0.15 & 29.5 & 2.80 & 0.50 \\
\hline
\end{tabular}


Table 2. Atmospheric Corrosion Data for Monel in ASTM Tests (Copson, 1955)

\begin{tabular}{|c|c|c|c|c|c|c|c|c|c|}
\hline \multirow{3}{*}{ Location } & \multirow{3}{*}{$\begin{array}{l}\text { Original } \\
\text { Weight, } \\
\text { g, avg }\end{array}$} & \multicolumn{4}{|c|}{ Loss in Weight } & \multicolumn{4}{|c|}{ Corrosion Rate } \\
\hline & & \multicolumn{2}{|c|}{ g, avg } & \multicolumn{2}{|c|}{ Per cent } & \multicolumn{2}{|c|}{ mdd } & \multicolumn{2}{|c|}{ mil per year } \\
\hline & & $10 \mathrm{yr}$ & $20 \mathrm{yr}$ & $10 \mathrm{yr}$ & $20 \mathrm{yr}$ & $10 \mathrm{yr}$ & $20 \mathrm{ys}$ & $10 \mathrm{yr}$ & $20 \mathrm{yr}$ \\
\hline Aitoona & 550.99 & 17.31 & 47.99 & 3.1 & 8.8 & 0.37 & 0.46 & 0.0596 & 0.0756 \\
\hline New York & 545.50 & 16.61 & 40.24 & 3.0 & 7.3 & 0.35 & 0.38 & 0.0564 & 0.0624 \\
\hline Sandy Hook & 544.88 & 7.90 & & 1.4 & & 0.16 & & 0.0266 & \\
\hline Key West & 560.21 & 1.93 & 2.76 & 0.3 & 0.5 & 0.04 & 0.03 & 0.0065 & 0.0045 \\
\hline La Jolla & 553.92 & 2.22 & 5.05 & 0.4 & 0.9 & 0.05 & 0.04 & 0.0077 & 0.0064 \\
\hline State College & 547.16 & 1.48 & 4.26 & 0.3 & 0.8 & 0.03 & 0.04 & 0.0050 & 0.0067 \\
\hline Phoenix & 550.84 & 0.48 & 1.24 & 0.1 & 0.2 & 0.01 & 0.01 & 0.0016 & 0.0020 \\
\hline
\end{tabular}


Table 3. Atmospheric Corrosion Data for Monel at Bayonne, N. J. (Copson, 1955)

\begin{tabular}{|c|c|c|c|c|c|c|c|}
\hline \multirow[b]{2}{*}{ Form } & \multirow[b]{2}{*}{$\begin{array}{l}\text { Exposure } \\
\text { Time, yr }\end{array}$} & \multirow[b]{2}{*}{$\begin{array}{c}\text { Date } \\
\text { Exposed }\end{array}$} & \multicolumn{3}{|c|}{ Corrosion Rate, mdd } & \multicolumn{2}{|c|}{$\begin{array}{l}\text { Pit Depth, avg of } \\
\text { deepest, mil }\end{array}$} \\
\hline & & & $\begin{array}{l}\text { Sheltered } \\
\text { Vertical } \\
\end{array}$ & $\begin{array}{l}\text { Exposed } \\
\text { Vertical }\end{array}$ & $\begin{array}{l}\text { Exposed } \\
\text { Inclined }\end{array}$ & $\begin{array}{l}\text { Sheltered } \\
\text { Vertical }\end{array}$ & $\begin{array}{l}\text { Exposed } \\
\text { Vertical } \\
\end{array}$ \\
\hline Sheet & 0.92 & $5 / 6 / 38$ & 0.63 & 0.27 & & & \\
\hline Sheet & 2.24 & $3 / 18 / 48$ & & & 0.44 & & \\
\hline Sheet & 11.88 & $8 / 23 / 40$ & 0.94 & 0.28 & & 2.80 & 9.40 \\
\hline $\begin{array}{l}\text { Screen } \\
\text { (16 mesh, } 0.009 \text {-in. wire) }\end{array}$ & 5.00 & $8 / 19 / 40$ & 2.15 & 1.15 & & & \\
\hline
\end{tabular}


Table 4. Corrosion Damage Data for Selected Metals Exposed in Various Atmospheric Environments (Southwell, et al., 1976)

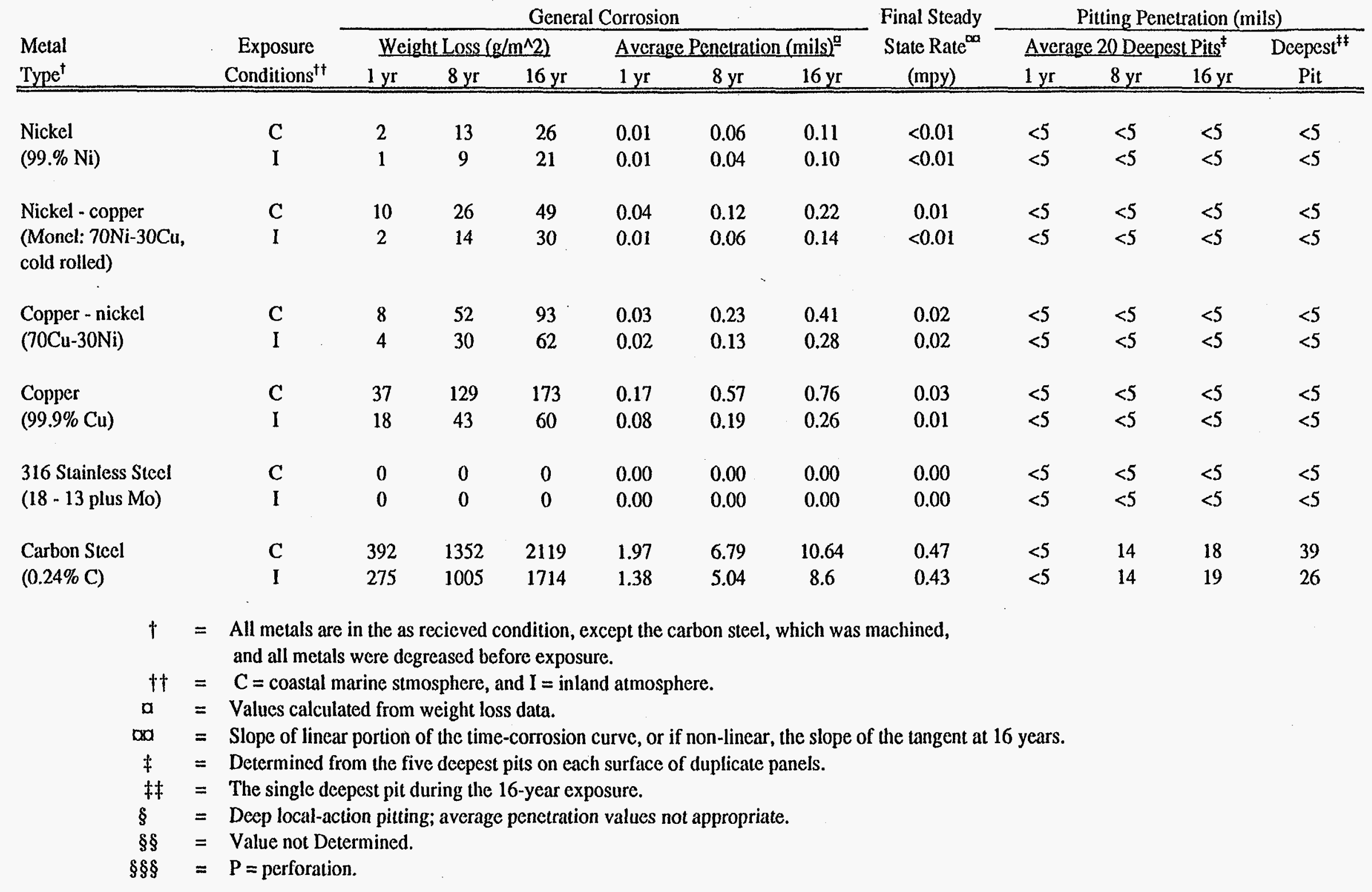


Table 5. Corrosion Damage Data for Selected Metals Exposed in Various Aqucous Environments (Southwell, et al., 1976)

\begin{tabular}{|c|c|c|c|c|c|c|c|c|c|c|c|c|}
\hline \multirow{3}{*}{$\begin{array}{l}\text { Metal } \\
\text { Type' } \\
\end{array}$} & \multirow{3}{*}{$\begin{array}{c}\text { Exposure } \\
\text { Conditions }{ }^{\prime t}\end{array}$} & \multicolumn{6}{|c|}{ General Corrosion } & \multirow{3}{*}{$\begin{array}{c}\text { Final Steady } \\
\text { State Rate } \\
\text { (mpy) } \\
\end{array}$} & \multicolumn{4}{|c|}{ Pitting Penetration (mils) } \\
\hline & & \multicolumn{3}{|c|}{ Weight Loss (g/m^2) } & \multicolumn{3}{|c|}{ Average Penetration (mils) ${ }^{n}$} & & \multicolumn{3}{|c|}{ Average 20 Dcepest Piss" } & \multirow{2}{*}{$\begin{array}{c}\text { Deepest }^{t t} \\
\text { Pit }\end{array}$} \\
\hline & & $1 y r$ & $8 \mathrm{yr}$ & $16 \mathrm{yr}$ & $1 \mathrm{yr}$ & $8 \mathrm{yr}$ & $16 \mathrm{yr}$ & & lyr & $8 \mathrm{yr}$ & $16 \mathrm{yr}$ & \\
\hline \multirow{3}{*}{$\begin{array}{l}\text { Nickel } \\
(99 . \% \mathrm{Ni})\end{array}$} & $\mathbf{S}$ & 540 & 2840 & 4340 & $2.40^{4}$ & $13.0^{4}$ & $19.0^{\prime}$ & $1.4^{4}$ & 125 & 120 & 192 & $p^{41}$ \\
\hline & $\mathbf{M}$ & 80 & 580 & 990 & 0.4 & 2.6 & 4.4 & 0.2 & $<5$ & 65 & 61 & 121 \\
\hline & L & 0.0 & 0.0 & 10 & 0.0 & 0.0 & 0.0 & 0.01 & $<5$ & $<5$ & $<5$ & $<5$ \\
\hline \multirow{3}{*}{$\begin{array}{l}\text { Nickel - copper } \\
\text { (Monel: } 70 \mathrm{Ni}-30 \mathrm{Cu} \text {, } \\
\text { cold rolled) }\end{array}$} & $\mathbf{S}$ & 370 & 1420 & 1950 & 1.6 & 6.3 & 8.7 & 0.3 & 17 & 40 & 34 & 55 \\
\hline & $\mathbf{M}$ & 20 & 300 & 600 & 0.1 & 1.3 & 2.7 & 0.2 & $<5$ & 14 & 14 & 24 \\
\hline & L & 0.0 & 30 & 140 & 0.0 & 0.1 & 0.6 & 0.04 & $<5$ & 12 & 17 & 53 \\
\hline Nickel - copper & $s$ & 470 & 1440 & 1870 & 2.1 & 6.4 & 8.4 & 0.3 & 43 & 50 & 56 & 82 \\
\hline (Monel: 70Ni-30Cu, & M & 30 & 310 & 570 & 0.1 & 1.4 & 2.6 & 0.2 & $<5$ & 17 & 24 & 36 \\
\hline hot rolled) & L & 11 & H & $" 1$ & 11 & $H$ & $" 1$ & 11 & 11 & 11 & "I & 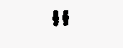 \\
\hline \multirow{3}{*}{$\begin{array}{l}\text { Copper - nickel } \\
(70 \mathrm{Cu}-30 \mathrm{Ni})\end{array}$} & $\mathrm{S}$ & 120 & 340 & 510 & 0.5 & 1.5 & 2.3 & 0.1 & $<5$ & $<5$ & $<5$ & 37 \\
\hline & M & 20 & 100 & 170 & 0.1 & 0.4 & 0.8 & 0.04 & $<5$ & $<5$ & $<5$ & $<5$ \\
\hline & L & 40 & 220 & 300 & 0.2 & 1.0 & 1.3 & 0.04 & $<5$ & $<5$ & $<5$ & $<5$ \\
\hline \multirow{3}{*}{$\begin{array}{l}\text { Copper } \\
(99.9 \% \mathrm{Cu})\end{array}$} & $\mathbf{S}$ & 270 & 1200 & 1360 & 1.2 & 5.3 & 6.0 & 0.09 & 20 & 28 & 31 & 57 \\
\hline & M & 150 & 250 & 300 & 0.7 & 1.1 & 1.3 & 0.02 & $<5$ & 10 & $<5$ & 23 \\
\hline & L & 50 & 190 & 230 & 0.2 & 0.8 & 1.0 & 0.02 & $<5$ & $<5$ & $<5$ & $<5$ \\
\hline \multirow{3}{*}{$\begin{array}{l}316 \text { Stainless Steel } \\
\text { (18-13 plus Mo) }\end{array}$} & $s$ & 120 & 410 & 160 & $0.6^{1}$ & $2.0^{\prime}$ & $0.8^{!}$ & 11 & $45 P^{\prime \prime \prime}$ & $156 \mathrm{P}^{\prime \prime \prime}$ & 95 & plli \\
\hline & M & 10 & 40 & 20 & 0.1 & 0.2 & 0.1 & 11 & 5 & 16 & 13 & 36 \\
\hline & L & 0.0 & 0.0 & 0.0 & 0.0 & 0.0 & 0.0 & 0.0 & $<5$ & $<5$ & $<5$ & $<5$ \\
\hline \multirow{3}{*}{$\begin{array}{l}\text { Carbon Stcel } \\
(0.24 \% \text { C) }\end{array}$} & $S$ & 1100 & 5390 & 9870 & 5.5 & 27.1 & 49.5 & 2.7 & 38 & 58 & 102 & plli \\
\hline & $\mathbf{M}$ & 2100 & 4950 & 8350 & 10.5 & 24.9 & 41.9 & 2.5 & 21 & 45 & 52 & 124 \\
\hline & $\mathrm{L}$ & 1500 & 4030 & 4880 & 7.5 & 20.2 & 24.5 & 0.6 & 22 & 60 & 65 & 94 \\
\hline
\end{tabular}

$\dagger=$ All metals are in the as recieved condition, except the carbon steel, which was machined, and all metals were degreased before exposurc.

t† $=S=$ sea continuous immersion, $M=$ sea mean tide, $L=$ lake, fresh water continuous immersion,

$a=$ Values calculated from weight loss data.

ad = Slope of linear portion of the time-corrosion curve, or if non-linear, the slope of the tangent at 16 years.

= Determined from the five decpest pits on each surface of duplicate panels.

\# = The single decpest pit during the 16-year exposure.

$\S \quad=$ Decp local-action pitting; average penetration values not appropriatc

$\S \S=$ Value not Determined.

$\S \S \S=\mathrm{P}=$ perforation. 
Table 6. Compositions of Nickel Base Alloys Exposed to the Atmosphere of Birmingham, Alabama (Evans, 1972)

\begin{tabular}{|l|c|c|c|c|c|c|c|c|c|c|c|}
\hline \multirow{2}{*}{ Material } & \multicolumn{10}{|c|}{ Compositions of Materials, Weight Percent } \\
\cline { 2 - 11 } & $\mathrm{C}$ & $\mathrm{Cr}$ & $\mathrm{Ni}$ & $\mathrm{Fe}$ & $\mathrm{Cu}$ & $\mathrm{Al}$ & $\mathrm{Si}$ & $\mathrm{Mn}$ & $\mathrm{S}$ & $\mathrm{P}$ \\
\hline Nickel 200 & 0.03 & 0.01 & $\mathrm{Bal}$. & 0.2 & $<0.01$ & Undet. & 0.14 & $<0.05$ & 0.002 & Undet. \\
Nickel 213 & 0.22 & 0.01 & $\mathrm{Bal}$ & 0.2 & 0.02 & Undet. & 0.17 & 2.11 & 0.003 & Undet. \\
Alloy 301 & 0.25 & 0.01 & $\mathrm{Bal}$. & 0.1 & $<0.01$ & 4.3 & 0.68 & 0.3 & $<0.002$ & Undet. \\
Alloy 600 & 0.09 & 14.5 & $\mathrm{Bal}$. & 6.8 & 0.2 & 0.1 & $<.2$ & 0.12 & $<0.002$ & Undet. \\
Alloy DS & 0.08 & 18.5 & 36 & $\mathrm{Bal}$. & 0.2 & Undet. & 2.36 & 1.15 & 0.007 & Undet. \\
Alloy 400 & 0.14 & 0.04 & $\mathrm{Bal}$. & 1.6 & 32.8 & Undet. & 0.06 & 1.1 & 0.006 & Undet. \\
Alloy K500 & 0.14 & $<0.01$ & $\mathrm{Bal}$ & 0.3 & 34.2 & Undet. & 0.3 & 0.25 & 0.003 & Undet. \\
55Cu/45Ni Alloy & 0.007 & 0.01 & 41 & 0.2 & Bal. & Undet. & 0.1 & 0.83 & 0.004 & Undet. \\
70/30 Copper-Nickel & 0.024 & $<0.01$ & 30.5 & 0.2 & Bal. & Undet. & $<0.05$ & 0.5 & 0.004 & 0.004 \\
80/20 Copper-Nickel & 0.003 & $<0.01$ & 20.5 & 0.2 & Bal. & Undet. & $<0.05$ & 0.3 & 0.003 & 0.003 \\
\hline
\end{tabular}




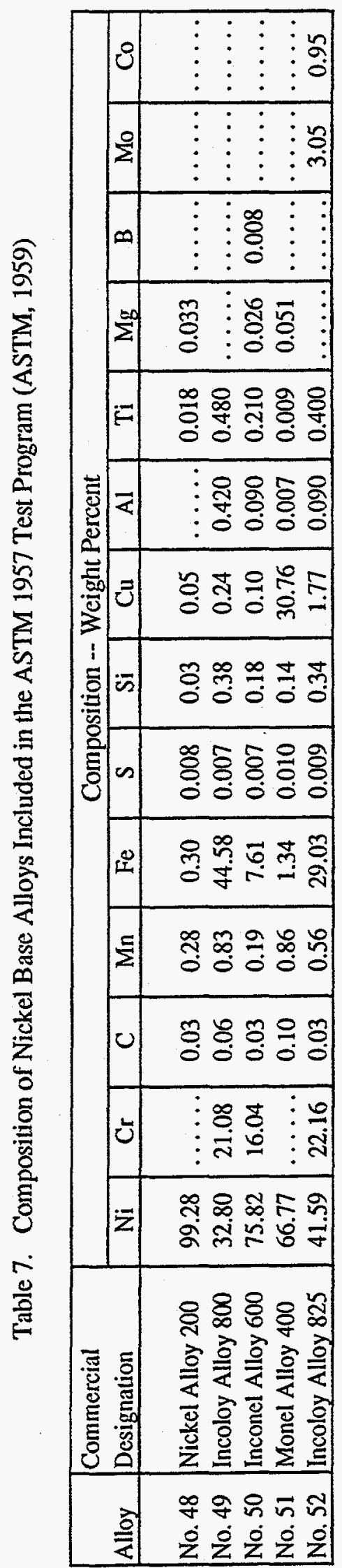


Table 8. Corrosion Data from the ASTM 1957 Test Program (ASTM, 1962; 1966)

\begin{tabular}{|c|c|c|c|c|c|c|c|c|c|}
\hline \multirow[b]{3}{*}{ Alloy } & \multirow{3}{*}{$\begin{array}{l}\text { Commercial } \\
\text { Designation }\end{array}$} & \multirow[b]{3}{*}{ Site ${ }^{(a)}$} & \multicolumn{4}{|c|}{ Corrosion Rate } & \multirow{2}{*}{\multicolumn{2}{|c|}{$\begin{array}{c}\text { Average } 4 \\
\text { Deepest Pits }\end{array}$}} & \multirow{3}{*}{$\begin{array}{l}\text { Maximum } \\
\text { Pit Depth } \\
7 \mathrm{yr}\end{array}$} \\
\hline & & & \multicolumn{2}{|c|}{ mg per dm per day } & \multicolumn{2}{|c|}{ mg per yr } & & & \\
\hline & & & $2 y \underline{z}$ & $7 \mathrm{yx}$ & $2 y \mathrm{~T}$ & $7 \mathrm{yr}$ & $2 \mathrm{yr}$ & $7 \mathrm{yx}$ & \\
\hline \multirow[t]{4}{*}{ No. 48} & Nickel Alloy 200 & A & 0.0753 & 0.0590 & 0.0123 & 0.0095 & 0.9 & 0.7 & 1.4 \\
\hline & & B & 0.4840 & 0.4282 & 0.0790 & 0.0652 & 0.9 & 0.8 & 1.1 \\
\hline & & C & 0.0423 & (b) & 0.0070 & (b) & 0.6 & (b) & (b) \\
\hline & & $\mathrm{D}$ & 0.0700 & 0.0058 & 0.0117 & 0.0090 & 0.7 & 0.5 & 0.6 \\
\hline \multirow[t]{4}{*}{ No. 49} & Incoloy Alloy 800 & A & 0.0320 & 0.0131 & 0.0060 & 0.0023 & 0.9 & 0.5 & 1.3 \\
\hline & & B & 0.0220 & 0.0045 & 0.0040 & 0.0008 & 0.7 & nil & nil \\
\hline & & C & 0.0287 & & 0.0057 & & 0.9 & (b) & (b) \\
\hline & & D & 0.0210 & 0.0046 & 0.0004 & 0.0008 & 0.7 & 0.3 & 0.6 \\
\hline \multirow[t]{4}{*}{ No. 50} & Inconel Alloy 600 & A & 0.0310 & 0.0108 & 0.0050 & 0.0018 & 1.1 & 0.7 & 1.3 \\
\hline & & B & 0.0270 & 0.0064 & 0.0043 & 0.0013 & 0.9 & 0.4 & 0.7 \\
\hline & & $\mathrm{C}$ & 0.0270 & (b) & 0.0043 & (b) & 1.0 & (b) & (b) \\
\hline & & D & 0.0160 & 0.0053 & 0.0030 & 0.0008 & 0.6 & 0.2 & 0.3 \\
\hline \multirow[t]{4}{*}{ No. 51} & Monel Alloy 400 & A & 0.1057 & 0.0878 & 0.0057 & 0.0143 & 0.6 & 0.6 & 0.7 \\
\hline & & $B$ & 0.2143 & 0.1957 & 0.0350 & 0.0318 & 0.9 & 0.9 & 1.4 \\
\hline & & $\mathrm{C}$ & 0.0690 & (b) & 0.0110 & & 0.6 & (b) & (b) \\
\hline & & $\mathrm{D}$ & 0.0710 & 0.0505 & 0.0110 & 0.0082 & 0.5 & 0.6 & 0.8 \\
\hline \multirow[t]{4}{*}{ No. 52} & Incoloy Alloy 825 & A & 0.0340 & 0.0074 & 0.0060 & 0.0013 & 0.6 & 0.5 & 0.7 \\
\hline & & B & 0.0257 & 0.0043 & 0.0047 & 0.0007 & 0.5 & 0.3 & 0.4 \\
\hline & & C & 0.0400 & (b) & 0.0067 & (b) & 0.4 & (b) & (b) \\
\hline & & $D$ & 0.0240 & 0.0046 & 0.0043 & 0.0008 & 0.4 & 0.3 & 0.5 \\
\hline
\end{tabular}

(a) A - Kure Beach (25-meter site), N.C., B - Newark, N.J., C- Point Reyes, Calif., D - State College, Pa.
(b) Panels lost. 
Table 9. Exposure Time for 1957 Test Program (ASTM, 1962;1966)

\begin{tabular}{|c|c|c|}
\hline \multirow{2}{*}{ Site } & \multicolumn{2}{|c|}{ Exposure Time, days } \\
\cline { 2 - 3 } & 2 year & 7 year \\
\hline A & 730 & 2557 \\
B & 734 & 2558 \\
C & 726 & $\ldots$. \\
D & 735 & 2538 \\
\hline
\end{tabular}


Table 10. Corrosion in Quiet Seawater After 3 Years Exposure (Boyd and Fink, 1975)

\begin{tabular}{|c|c|c|c|c|c|c|c|}
\hline \multirow[b]{2}{*}{ Material } & \multirow{2}{*}{$\begin{array}{c}\text { Thickness, } \\
\text { inch }\end{array}$} & \multirow{2}{*}{$\begin{array}{l}\text { Fouling } \\
\text { Rate }^{(a)}\end{array}$} & \multirow{2}{*}{$\begin{array}{l}\text { Weight } \\
\text { Loss, } \\
\text { grams }\end{array}$} & \multirow{2}{*}{$\begin{array}{c}\text { Corrosion } \\
\text { Rate, } \\
\text { mpy }\end{array}$} & \multicolumn{2}{|c|}{$\begin{array}{c}\text { Localized } \\
\text { Attack, mils }\end{array}$} & \multirow[b]{2}{*}{ Remarks } \\
\hline & & & & & $\operatorname{Max}$ & $\mathrm{Ave}^{(\mathrm{b})}$ & \\
\hline \multirow[t]{2}{*}{ Monel Alloy 400} & 0.062 & 2 & 36.6 & (c) & 41 & 36 & Numerous broad pits. \\
\hline & 0.062 & 2 & 34.2 & (c) & 52 & 48 & Numerous broad pits, single perforation from opposing pits. \\
\hline \multirow[t]{2}{*}{ Monel Alloy K500 } & 0.125 & 2 & 33 & (c) & 39 & 30 & Numerous broad pits, 5.8 mils; deeper attack in large areas on back side. \\
\hline & 0.125 & 2 & 32.6 & (c) & 55 & 33 & Crevice corrosion beneath barnacles and at sheared edges. \\
\hline \multirow[t]{2}{*}{304 stainless steel } & 0.125 & 2 & 16.8 & (c) & \multicolumn{2}{|c|}{ Perforated } & Crevice corrosion beneath barnacles and at sheared edges. \\
\hline & 0.125 & 2 & 17.4 & (c) & 119 & 42 & Crevice corrosion beneath barnacles and at sheared edges. \\
\hline \multirow[t]{2}{*}{316 stainiess steel } & 0.125 & 2 & 4 & (c) & 72 & 50 & Crevice corrosion beneath barnacles and at sheared edges. \\
\hline & 0.125 & 2 & 4.8 & (c) & 60 & 45 & Crevice corrosion beneath barnacles and at sheared edges. \\
\hline \multirow[t]{2}{*}{ Incoloy Alloy 825} & 0.125 & 1 & 0.2 & 0.1 & 7 & 1 & Crevice corrosion beneath barnacles. \\
\hline & 0.125 & 1 & 0.2 & 0.1 & 1 & 1 & Crevice corrosion beneath barnacles. \\
\hline
\end{tabular}

Note - Specimen dimensions, $4 \times 12$ inches.

(a) $10=$ frec of fouling, $0=$ completcly foulcd. A values of 2 indicates that 80 percent of the sample surface was fouled.

(b) Average five deepest pits.

(c) Weight loss due to localized corrosion. 
Table 11. Sea Water Analysis for Jet Impingement and Static Immersion Tests ( $\mathrm{g} / \mathrm{L}$ ) (White, et al., 1966)

\begin{tabular}{|l|c|c|c|c|c|c|c|}
\hline Component & $\mathrm{Na}$ & $\mathrm{K}$ & $\mathrm{Ca}$ & $\mathrm{Mg}$ & $\mathrm{Cl}$ & $\mathrm{SO}_{4}$ & $\mathrm{Br}$ \\
\hline Mediterranean Sea & 10.8 & 0.39 & 0.4 & 1.3 & 19.4 & 3 & 0.07 \\
Dead Sea & 33 & 6 & 13 & 36 & 181 & 1 & 4.5 \\
\hline
\end{tabular}


Table 12. Corrosion Data for Impingement Test (White, et al., 1966)

\begin{tabular}{|c|l|c|c|c|c|c|c|}
\hline \multirow{2}{*}{$\begin{array}{c}\text { Expt. } \\
\text { No. }\end{array}$} & Exposure & \multicolumn{2}{|c|}{ Monel } & \multicolumn{2}{c|}{ 70/30 Copper-nickel } & \multicolumn{2}{c|}{ Stainless steel (18:8) } \\
\cline { 3 - 7 } & Weight Loss $(\mathrm{mg})$ & Pit Depth $(\mu \mathrm{m})$ & Weight Loss (mg) & Pit Depth $(\mu \mathrm{m})$ & Weight Loss (mg) & Pit Depth $(\mu \mathrm{m})$ \\
\hline 12 & Mediterranean Sea & 91 & 5 & 198 & 105 & 10 & 3 \\
13 & Mediterranean Sea & 135 & 5 & 150 & 50 & $(\mathrm{a})$ & 3 \\
10 & Dead Sea & 36 & 5 & 89 & 50 & $(\mathrm{a})$ & 0 \\
11 & Dead Sea & 18 & 10 & 75 & 20 & 3 & 0 \\
\hline
\end{tabular}

(a) Value not determined. 
Table 13. Corrosion Data for Total Immersion Test (White, et al., 1966)

\begin{tabular}{|c|c|c|c|c|}
\hline \multirow[b]{2}{*}{ Exposure } & \multirow{2}{*}{$\begin{array}{l}\text { Test Duration } \\
\text { (days) }\end{array}$} & \multicolumn{3}{|c|}{ Average Rate of Penetration $(\mu \mathrm{m} / \mathrm{day})$} \\
\hline & & Monel & $70 / 30$ Copper-nickel & Stainless Steel $(18: 8)$ \\
\hline Mediterranean Sea & 84 & & 0.0048 & \\
\hline Mediterranean Sea & 120 & 0.002 & & 0.0015 \\
\hline Mediterranean Sea & 165 & & 0.0018 & \\
\hline Dead Sea & 31 & & 0.048 & \\
\hline Dead Sea & 84 & & 0.0384 & \\
\hline Dead Sea & 120 & 0.0042 & & 0.0131 \\
\hline
\end{tabular}


Table 14. Corrosion Data for Partial Immersion Test (White, et al., 1966)

\begin{tabular}{|l|c|c|c|c|}
\hline & Test Duration & \multicolumn{3}{|c|}{ Rate of Loss in Weight (mg/day) } \\
\cline { 3 - 5 } Exposure & (days) & Monel & Stainless Steel (18:8) & Mild Carbon-steel \\
\hline Mediterranean Sea & 103 & & & $5.0,5.1$ \\
Mediterranean Sea & 120 & 0.05 & 0.016 & \\
Dead Sea & 103 & & & $1.4,1.4$ \\
Dead Sea & 120 & 0.075 & 0.17 & \\
\hline
\end{tabular}


Table 15. Results of General Corrosion Rates of Metals in Deep-Ocean Environments (Wheatfall, 1967)

\begin{tabular}{|c|c|c|c|c|c|}
\hline \multirow[b]{2}{*}{ Alloy Designation } & \multirow[b]{2}{*}{ Exposure Depth } & \multirow[b]{2}{*}{ Exposure time, days } & \multirow[b]{2}{*}{ Corrosion Rate, $\mathrm{mdd}^{(\mathrm{a})}$} & \multicolumn{2}{|c|}{ Comments } \\
\hline & & & & $\begin{array}{c}\text { Surface Attack } \\
\text { (outside crevice area) }\end{array}$ & $\begin{array}{c}\text { Crevice Attack } \\
\text { (maximum pit depth, mm) }\end{array}$ \\
\hline \multirow[t]{4}{*}{ AISI Type 304} & $5640 \mathrm{ft}$ & 123 & $5.91^{(0)}$ & No visible pits. & 0.7874 - inside crevice. \\
\hline & $5640 \mathrm{ft}$ & 751 & $8.51^{(b)}$ & Scaltered severe pitting and edge attack. & 3.175 - inside crevice (perforated). \\
\hline & $5300 \mathrm{ft}$ & 1064 & $5.31^{(b)}$ & Scattered severe pitting and edge attack. & 3.175 - inside crevice (perforated). \\
\hline & Surface & 386 & $3.15^{(b)}$ & $\begin{array}{l}\text { Altack along all edges and scattered perforations } \\
(1.6 \mathrm{~mm}) \text {. }\end{array}$ & 1.6 - inside crevice (perforated). \\
\hline \multirow[t]{4}{*}{ Cupro-Nickel 30\% } & $5640 \mathrm{ft}$ & 123 & 6.27 & Etched surface. & No altack. \\
\hline & $5640 \mathrm{ft}$ & 751 & 2.75 & Etched and streaked surface. & Slight attack at crevice entrance. \\
\hline & $5300 \mathrm{ft}$ & 1064 & 3.08 & Etched and streaked surface. & Slight attack at crevice entrance. \\
\hline & Surface & 386 & 1.42 & Etched surface. & Slight attack at crevice entrance. \\
\hline \multirow[t]{3}{*}{ Monel Alloy 400} & $5640 \mathrm{ft}$ & 123 & 3.06 & Etched, tarnished, and streaked surface. & $\begin{array}{l}\text { Incipient - inside and at entrance of } \\
\text { crevice. }\end{array}$ \\
\hline & $5640 \mathrm{ft}$ & 751 & $0.738^{(b)}$ & Etched, tarnished, and streaked surface. & 0.33 - inside and at entrance of crevice. \\
\hline & Surface & 386 & $8.03^{(b)}$ & Severe surface pitting to $0.51 \mathrm{~mm}$. & $\begin{array}{l}1.6 \text { - inside and at entrance of crevice } \\
\text { (perforated). }\end{array}$ \\
\hline \multirow[t]{3}{*}{ Mond Alloy K500 } & $5640 \mathrm{ft}$ & 123 & $4.37^{(b)}$ & Eitched surface. & 0.28 - inside and at entrance of crevice. \\
\hline & $5640 \mathrm{ft}$ & 751 & $2.26^{(b)}$ & General surface pitting to $0.2032 \mathrm{~mm}$. & $\begin{array}{l}1.6 \text { - inside and at entrance of crevice } \\
\text { (perforated). }\end{array}$ \\
\hline & Surface & 386 & $7.97^{(b)}$ & General surface pitting to $0.8382 \mathrm{~mm}$. & $\begin{array}{l}1.6-\text { inside and at entrance of crevice } \\
\text { (perforated). }\end{array}$ \\
\hline \multirow[t]{3}{*}{ Incoloy Alloy 825} & $5640 \mathrm{ft}$ & 123 & 0.634 & No visible attack. & Incipient - inside crevice. \\
\hline & $5640 \mathrm{ft}$ & 751 & $2.31^{(b)}$ & Scattered pitting to $0.025 \mathrm{~mm}$. & 1.6 - inside crevice (perforated). \\
\hline & Surface & 386 & $0.218^{(b)}$ & Scattered pitting to $0.051 \mathrm{~mm}$. & 1.45 - inside crevice. \\
\hline
\end{tabular}

(a) mdd = milligrams per square decimeter per day.

(b) Weight loss attributed largely to localized corrosion. 
Table 16. Operating Conditions for Corrosion Test Packages at a Geothermal Test Facility (see Figure 7) (Cramer, et al., 1983)

\begin{tabular}{|l|c|c|c|c|}
\hline \multicolumn{1}{|c|}{ Corrosion test packages } & Temp., ${ }^{\circ} \mathrm{C}$ & $\begin{array}{c}\text { Absolute } \\
\text { pressure, } \\
\mathrm{MPa}\end{array}$ & $\mathrm{pH}$ & {$[\mathrm{Cl}], \mathrm{ppm}$} \\
\hline P1 and electrochemical package & 215 & 2.00 & 5.3 & 115,000 \\
(wellhead brine) & 199 & 1.63 & 5.7 & 127,000 \\
P2 (brine from separator 1) & 199 & 1.63 & 6.2 & 8,100 \\
P3 (steam from separator 1) & 180 & 1.02 & 5.8 & 129,000 \\
P4 (brine from separator 2) & 180 & 1.02 & 6.9 & 1,700 \\
\hline P5 (steam from separator 2) & & & \\
\hline
\end{tabular}

Note -- Input flow rate $=130 \mathrm{~L} / \mathrm{min}$ 
Table 17. Composition in Weight Percent of Nickel-Base Alloys Exposed to Brine and Steam Systems (Cramer, et al., 1983)

\begin{tabular}{|c|c|c|c|c|c|c|c|}
\hline Alloy & $\overline{\mathrm{Ni}}$ & $\mathrm{Cr}$ & $\overline{\mathrm{Fe}}$ & $\mathrm{Cu}$ & Mo & $\mathrm{Mn}$ & Other \\
\hline Nickel 201 & bal & $\bar{\cdots}$ & $\cdots$ & $\cdots$ & $\cdots$ & $\cdots$ & $\cdots$ \\
\hline Monel Alloy 400 & bal & $\ldots$ & 1.25 & 31.5 & $\cdots$ & $2.00 \max$ & - \\
\hline Monel Alloy 404 & bal & $\cdots$ & 0.5 & 44 & $\ldots$ & $\ldots$ & $\ldots$ \\
\hline Inconel Alloy 825 & bal & 21.5 & 30 & 2.25 & 3 & $-\ldots$ & $0.9 \mathrm{Ti}$ \\
\hline Hastelloy Alloy G & bal & 21.7 & 19.1 & 1.84 & 6.8 & 1.42 & $1.22 \mathrm{Co}-2.15(\mathrm{Nb}+\mathrm{Ta})-0.45 \mathrm{Si}-0.17 \mathrm{~W}$ \\
\hline
\end{tabular}


Table 18. General Corrosion Rates for Nickel Alloys in Brine and in Steam, $\mu \mathrm{m} / \mathrm{yr}$ (Cramer, et al., 1983)

\begin{tabular}{|c|ccc|}
\hline & \multicolumn{3}{|c|}{ Exposure, days } \\
\cline { 2 - 4 } Alloy & $15^{2}$ & 30 & 45 \\
\hline Wellhead brine (P1) & & & \\
Nickel 201 & (b) & (b) & (b) \\
Monel 400 & 716 & 533 & 356 \\
Monel 404 & 767 & 432 & 279 \\
Incoloy 825 & 117 & 73.7 & 35.6 \\
Hastelloy G & 15.2 & 0.0 & 2.5 \\
Brine 1 (P2) & & & \\
Nickel 201 & (b) & $302^{(c)}$ & $($ b) \\
Monel 400 & 209 & 112 & 91.4 \\
Monel 404 & 343 & 190 & 152 \\
Incoloy 825 & 7.6 & 10.2 & 2.5 \\
Hastelloy G & 0.0 & 0.0 & 0.0 \\
Brine 2 (P4) & & & \\
Nickel 201 & $287^{(c)}$ & $(b)$ & $(b)$ \\
Monel 400 & 119 & 117 & 71.1 \\
Monel 404 & 188 & 114 & 81.3 \\
Incoloy 825 & 7.6 & 7.6 & 2.5 \\
Hastelloy G & 2.5 & $($ (b) & 0.0 \\
\hline
\end{tabular}

a Average of results from four 15 - day tests.

b No samples were exposed.

c One sample. 
Table 19. Maximum and Average Pit Penetration Rates for Nickel Alloys in Brine and in Steam, $\mu \mathrm{m} / \mathrm{yr}$ (Cramer, et al., 1983)

\begin{tabular}{|c|c|c|c|c|c|c|}
\hline \multirow[b]{3}{*}{ Alloy } & \multicolumn{6}{|c|}{ Exposure, days } \\
\hline & \multicolumn{2}{|c|}{$15^{\mathrm{a}}$} & \multicolumn{2}{|c|}{30} & \multicolumn{2}{|c|}{45} \\
\hline & $\operatorname{Max}$ & Avg & $\operatorname{Max}$ & Avg & $\operatorname{Max}$ & Avg \\
\hline \multicolumn{7}{|l|}{ Wellhead brine (P1) } \\
\hline Monel 400 & 1480 & (b) & 450 & (b) & 350 & (b) \\
\hline Monel 404 & 2340 & (b) & 900 & (b) & 330 & (b) \\
\hline Incoloy 825 & 4510 & 1940 & 2160 & 1210 & 968 & 680 \\
\hline Hastelloy G & 4880 & 1400 & 770 & (b) & 740 & 310 \\
\hline \multicolumn{7}{|l|}{ Brine 1 (P2) } \\
\hline Monel 400 & 1550 & 870 & 740 & (b) & 740 & 430 \\
\hline Monel 404 & 1410 & (b) & 1330 & 740 & 520 & 310 \\
\hline Incoloy 825 & 5810 & 2290 & 1060 & 680 & 1150 & 740 \\
\hline Hastelloy G & 2330 & (o) & (c) & (c) & 240 & (b) \\
\hline \multicolumn{7}{|l|}{ Brine 2 (P4) } \\
\hline Monel 400 & 2350 & 930 & 610 & 420 & 410 & 260 \\
\hline Monel 404 & 2820 & 870 & 640 & 380 & 450 & 260 \\
\hline Incoloy 825 & 1870 & 900 & 990 & 920 & 720 & 450 \\
\hline Hastelloy G & 2150 & 730 & $<320$ & (b) & 850 & 390 \\
\hline \multicolumn{7}{|l|}{ Steam $1(\mathrm{P} 3)$} \\
\hline Monel 400 & 1360 & 660 & 430 & 280 & 560 & (b) \\
\hline Monel 404 & 2160 & 820 & 930 & 400 & 390 & 210 \\
\hline Incoloy 825 & 3460 & 1420 & 1110 & 680 & 780 & 390 \\
\hline Hastelloy G & 810 & (b) & 1150 & (b) & 400 & (b) \\
\hline Steam 2 (P5) & & & & & & \\
\hline Monel 400 & 1740 & 830 & 610 & 400 & 350 & (b) \\
\hline Monel 404 & 2410 & 970 & 480 & 350 & 500 & 330 \\
\hline Incoloy 825 & 2270 & 830 & 1570 & 900 & 800 & 370 \\
\hline Hastelloy G & (c) & (c) & 800 & $<260$ & 370 & $<170$ \\
\hline
\end{tabular}

Average of results from four 15 - day tests.

b Less than five pits per coupon.

- No pitting. 
Table 20. Galvanic Corrosion Data for Atmospheric Exposure (Pelensky, et al., 1978)

\begin{tabular}{|c|c|c|c|c|c|c|c|c|}
\hline \multirow[b]{2}{*}{ Alloy } & \multirow{2}{*}{$\begin{array}{c}\text { Exposure, } \\
\text { months }\end{array}$} & \multicolumn{7}{|c|}{ Corrosion Rates, mm/year } \\
\hline & & AZ31 Magnesium & 316 Stainless Stcel & 4340 Steel & 6061-T6 Aluminum & 7075-T6 Aluminum & 360 Brass & 400 Monel \\
\hline \multirow[t]{5}{*}{ AZ31 Magnesium } & 2 & 0.031 & 0.076 & 0.096 & 0.047 & 0.047 & 0.074 & 0.092 \\
\hline & 4 & 0.037 & 0.079 & 0.089 & 0.050 & 0.040 & 0.066 & 0.077 \\
\hline & 8 & 0.034 & 0.057 & 0.064 & 0.048 & 0.048 & 0.064 & 0.059 \\
\hline & 15 & 0.025 & 0.045 & 0.049 & 0.036 & 0.037 & 0.048 & 0.052 \\
\hline & 24 & 0.028 & 0.061 & 0.076 & 0.040 & 0.039 & 0.051 & 0.049 \\
\hline \multirow[t]{5}{*}{4340 Steel } & 2 & 0.033 & 0.071 & 0.069 & 0.069 & 0.061 & 0.068 & 0.074 \\
\hline & 4 & 0.018 & 0.050 & 0.055 & 0.055 & 0.050 & 0.050 & 0.050 \\
\hline & 8 & 0.014 & 0.036 & 0.037 & 0.038 & 0.036 & 0.036 & 0.036 \\
\hline & 15 & 0.013 & 0.047 & 0.046 & 0.030 & 0.031 & 0.038 & 0.044 \\
\hline & 24 & 0.011 & 0.049 & 0.048 & 0.026 & 0.025 & 0.037 & 0.049 \\
\hline 6061-T6 & 2 & 0.002 & 0.006 & 0.005 & 0.002 & 0.002 & 0.006 & 0.005 \\
\hline \multirow[t]{4}{*}{ Aluminum } & 4 & 0.001 & 0.002 & 0.006 & 0.002 & 0 & 0.004 & 0.002 \\
\hline & 8 & 0.001 & 0.001 & 0.004 & 0.001 & 0.001 & 0.002 & 0.001 \\
\hline & 15 & 0 & 0.002 & 0.006 & 0.001 & 0.001 & 0.003 & 0.003 \\
\hline & 24 & 0 & 0.003 & 0.007 & 0.001 & 0.001 & 0.007 & 0.003 \\
\hline 7075-T6 & 2 & 0.003 & 0.007 & 0.009 & 0.005 & 0.003 & 0.010 & 0.007 \\
\hline \multirow[t]{4}{*}{ Aluminum } & 4 & 0.002 & 0.005 & 0.005 & 0.002 & 0.003 & 0.004 & 0.003 \\
\hline & 8 & 0.001 & 0.003 & 0.004 & 0.001 & 0.001 & 0.003 & 0.003 \\
\hline & 15 & 0 & 0.003 & 0.016 & 0.002 & 0.001 & 0.005 & 0.003 \\
\hline & 24 & 0 & 0.003 & 0.012 & 0.002 & 0.001 & 0.010 & 0.003 \\
\hline \multirow[t]{5}{*}{360 Brass } & 2 & 0.003 & 0.009 & 0.006 & 0.005 & 0.005 & 0.007 & 0.008 \\
\hline & 4 & 0.001 & 0.004 & 0.003 & 0.002 & 0.002 & 0.003 & 0.004 \\
\hline & 8 & 0.001 & 0.002 & 0.002 & 0.001 & 0.001 & 0.001 & 0.002 \\
\hline & 15 & 0.001 & 0.002 & 0.002 & 0.001 & 0.001 & 0.001 & 0.001 \\
\hline & 24 & 0 & 0.002 & 0.002 & 0.001 & 0.001 & 0.001 & 0.001 \\
\hline
\end{tabular}

Note -- Essentially zero corrosion rate for Type 316 stainless stecl and 400 Moncl specimens. 
Table 21. Galvanic Corrosion Data for Soil Exposure (Pelensky, et al., 1978)

\begin{tabular}{|c|c|c|c|c|c|c|c|c|}
\hline Alloy & $\begin{array}{c}\text { Exposure, } \\
\text { months }\end{array}$ & \multicolumn{7}{|c|}{ Corrosion Rates, $\mathrm{mm} /$ year } \\
\hline AZ31 Magnesium & $\begin{array}{c}2 \\
6 \\
12 \\
25\end{array}$ & $\begin{array}{l}0.093 \\
0.137 \\
0.045 \\
0.029\end{array}$ & $\begin{array}{l}1.398 \\
0.953 \\
1.225 \\
0.490\end{array}$ & $\begin{array}{l}1.920 \\
1.099 \\
1.080 \\
0.580\end{array}$ & $\begin{array}{l}0.264 \\
0.164 \\
0.093 \\
0.056\end{array}$ & $\begin{array}{l}0.551 \\
0.233 \\
0.208 \\
0.109\end{array}$ & $\begin{array}{l}0.967 \\
0.932 \\
0.848 \\
0.561\end{array}$ & $\begin{array}{l}1.322 \\
0.936 \\
0.912 \\
0.603\end{array}$ \\
\hline $\begin{array}{l}\text { 6061-T6 } \\
\text { Aluminum }\end{array}$ & $\begin{array}{c}2 \\
6 \\
12 \\
25\end{array}$ & $\begin{array}{l}0.067 \\
0.017 \\
0.009 \\
0.003\end{array}$ & $\begin{array}{l}0.003 \\
0.008 \\
0.008 \\
0.006\end{array}$ & $\begin{array}{l}0.003 \\
0.001 \\
0.006 \\
0.003\end{array}$ & $\begin{array}{l}0.003 \\
0.005 \\
0.002 \\
0.001\end{array}$ & $\begin{array}{l}0.003 \\
0.009 \\
0.001 \\
0.005\end{array}$ & $\begin{array}{l}0.004 \\
0.011 \\
0.010 \\
0.007\end{array}$ & $\begin{array}{l}0.007 \\
0.013 \\
0.011 \\
0.008\end{array}$ \\
\hline 360 Brass & $\begin{array}{c}2 \\
6 \\
12 \\
25\end{array}$ & $\begin{array}{c}0.004 \\
0.001 \\
0 \\
0.001\end{array}$ & $\begin{array}{l}0.016 \\
0.015 \\
0.012 \\
0.007\end{array}$ & $\begin{array}{c}0.006 \\
0.001 \\
0 \\
0\end{array}$ & $\begin{array}{c}0.006 \\
0.001 \\
0.001 \\
0\end{array}$ & $\begin{array}{c}0.005 \\
0.001 \\
0 \\
0.001\end{array}$ & $\begin{array}{l}0.005 \\
0.007 \\
0.005 \\
0.004\end{array}$ & $\begin{array}{l}0.005 \\
0.014 \\
0.009 \\
0.008\end{array}$ \\
\hline 400 Monel & $\begin{array}{c}2 \\
6 \\
12 \\
25 \\
\end{array}$ & $\begin{array}{c}0 \\
0.001 \\
0 \\
0 \\
\end{array}$ & $\begin{array}{l}0.003 \\
0.009 \\
0.010 \\
0.007\end{array}$ & $\begin{array}{c}0.001 \\
0 \\
0 \\
0 \\
\end{array}$ & $\begin{array}{c}0.001 \\
0.001 \\
0.001 \\
0 \\
\end{array}$ & $\begin{array}{c}0.001 \\
0.001 \\
0 \\
0 \\
\end{array}$ & $\begin{array}{l}0.001 \\
0.004 \\
0.002 \\
0.002 \\
\end{array}$ & $\begin{array}{l}0.001 \\
0.005 \\
0.004 \\
0.004 \\
\end{array}$ \\
\hline
\end{tabular}

Note -- Essentially zero corrosion rate for Type 316 stainless steel specimens. 
Table 22. Galvanic Corrosion Data for Seawater Immersion (Pelensky, et al., 1978)

\begin{tabular}{|c|c|c|c|c|c|c|c|c|}
\hline \multirow[b]{2}{*}{ Alloy } & \multirow[b]{2}{*}{$\begin{array}{c}\text { Exposure, } \\
\text { months }\end{array}$} & \multicolumn{7}{|c|}{ Corrosion Rates, mm/year } \\
\hline & & $\begin{array}{c}\text { AZ31 } \\
\text { Magnesium } \\
\end{array}$ & $\begin{array}{c}316 \\
\text { Stainless } \\
\end{array}$ & $\begin{array}{l}4340 \\
\text { Steel } \\
\end{array}$ & $\begin{array}{c}\text { 6061-T6 } \\
\text { Aluminum } \\
\end{array}$ & $\begin{array}{c}\text { 7075-T6 } \\
\text { Aluminum }\end{array}$ & $\begin{array}{c}360 \\
\text { Brass } \\
\end{array}$ & $\begin{array}{c}400 \\
\text { Monel } \\
\end{array}$ \\
\hline$A Z 31$ & 2 & 1.581 & SM & SM & 2.336 & 5.64 & 12.122 & (b) \\
\hline \multirow[t]{4}{*}{ Magnesium } & 4. & 1.293 & $\ldots \ldots$ & $\ldots \ldots$ & 2.149 & 4.732 & 7.66 & (b) \\
\hline & 7 & 1.021 & & & 1.724 & 6.165 & (b) & 6.281 \\
\hline & 12 & 0.811 & $\cdots$ & $\cdot$ & (b) & (b) & (b) & (b) \\
\hline & 18 & $\mathrm{SM}^{(\mathrm{a})}$ & $\ldots \ldots$ & $\ldots \ldots$ & 1.628 & $\cdots$ & $\cdots$ & (b) \\
\hline 316 Stainless & 2 & 0 & $0.097^{(\mathrm{c})}$ & 0 & 0 & 0 & 0 & $0.105^{(\mathrm{c})}$ \\
\hline \multirow[t]{4}{*}{ Steel } & 4 & 0 & $0.034^{(\mathrm{c})}$ & 0 & 0 & 0 & 0 & $0.033^{(\mathrm{c})}$ \\
\hline & 7 & 0 & $0.036^{(\mathrm{c})}$ & 0 & 0 & 0 & 0 & $0.061^{(\mathrm{c})}$ \\
\hline & 12 & 0 & $0.013^{(\mathrm{c})}$ & 0 & 0 & 0 & 0 & $0.028^{(\mathrm{c})}$ \\
\hline & 18 & 0.003 & $0.551^{(c)}$ & 0 & 0 & 0 & 0 & .... \\
\hline \multirow[t]{5}{*}{4340 Steel } & 2 & 0.024 & 1.143 & 0.635 & 0.018 & 0.020 & 1.257 & 1.238 \\
\hline & 4 & 0.093 & 0.831 & 0.468 & 0.004 & 0.006 & 0.802 & 0.813 \\
\hline & 7 & SM & 0.770 & 0.612 & 0.012 & 0.014 & 0.921 & 0.922 \\
\hline & 12 & SM & 0.436 & 0.289 & 0.005 & 0.004 & 0.542 & 0.453 \\
\hline & 18 & SM & 0.596 & 0.338 & 0.005 & 0.004 & 0.504 & 0.535 \\
\hline $6061-\mathrm{T} 6$ & 2 & 0.449 & 0.378 & 0.252 & 0.043 & 0.073 & 0.437 & 0.385 \\
\hline \multirow[t]{4}{*}{ Aluminum } & 4 & 0.782 & 0.275 & 0.176 & 0.021 & 0.024 & 0.233 & 0.256 \\
\hline & 7 & 0.864 & 0.302 & 0.189 & 0.017 & 0.017 & 0.288 & 0.288 \\
\hline & 12 & 0.698 & 0.171 & 0.107 & 0.007 & 0.010 & 0.186 & 0.200 \\
\hline & 18 & 0.645 & 0.139 & 0.081 & 0.006 & 0.031 & 0.118 & 0.148 \\
\hline 7075-T6 & 2 & 5.143 & 0.465 & 0.340 & 0.013 & 0.040 & 0.411 & 0.490 \\
\hline \multirow[t]{4}{*}{ Aluminum } & 4 & 4.145 & 0.303 & 0.187 & 0.009 & 0.029 & 0.301 & 0.298 \\
\hline & 7 & 3.563 & 0.297 & 0.253 & 0.016 & 0.023 & 0.275 & 0.229 \\
\hline & 12 & 2.097 & 0.212 & 0.135 & 0.002 & 0.014 & 0.189 & 0.193 \\
\hline & 18 & 1.445 & 0.086 & 0.113 & 0.002 & 0.049 & 0.142 & 0.172 \\
\hline \multirow[t]{5}{*}{360 Brass } & 2 & 0.009 & 0.339 & 0.006 & 0.007 & 0.005 & 0.124 & 0.293 \\
\hline & 4 & 0.004 & 0.184 & 0.003 & 0.005 & 0.002 & 0.106 & 0.190 \\
\hline & 7 & 0.004 & 0.159 & 0.008 & 0.022 & 0.008 & 0.190 & 0.223 \\
\hline & 12 & 0.002 & 0.130 & 0.002 & 0.001 & 0.002 & 0.139 & 0.160 \\
\hline & 18 & 0.001 & 0.110 & 0.001 & 0.001 & 0.001 & 0.115 & 0.146 \\
\hline \multirow[t]{5}{*}{400 Monel } & 2 & 0.001 & 0.011 & 0.001 & 0.001 & 0 & 0.002 & 0.034 \\
\hline & 4 & 0.001 & 0.015 & 0.001 & 0.001 & 0 & 0.002 & 0.006 \\
\hline & 7 & 0.001 & 0.009 & 0.002 & 0.001 & 0.001 & 0.002 & 0.008 \\
\hline & 12 & 0.001 & 0.006 & 0.001 & 0 & 0.001 & 0.002 & 0.007 \\
\hline & 18 & 0.001 & 0.015 & 0.001 & 0 & 0 & 0.001 & 0.027 \\
\hline
\end{tabular}

\footnotetext{
(a) $\mathrm{SM}=$ Specimens missing.

(b) Total dissolution of magnesium presumed.

(e) Stainless steel attack - crevice pitting.
} 
Table 23. Corrosion Penetration for Strip Metal of Galvanic Couples Exposed to Various Waters in the Panama Canal Zone for Periods of up to 16 Years

(Southwell \& Alexander, 1976)

\begin{tabular}{|c|c|c|c|c|c|c|c|c|c|c|c|c|c|c|c|}
\hline \multirow{3}{*}{$\begin{array}{l}\text { Strip } \\
\text { (2x9xi/4 in) }\end{array}$} & \multirow{3}{*}{$\begin{array}{l}\text { Piale } \\
(9 \times 9 \times 1 / 4 \text { in) }\end{array}$} & \multicolumn{14}{|c|}{ 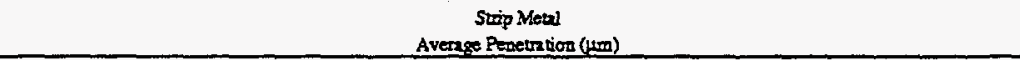 } \\
\hline & & \multicolumn{4}{|c|}{ Sen Wazer } & \multicolumn{2}{|l|}{ 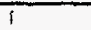 } & \multicolumn{2}{|c|}{ Mean Tide } & \multirow[b]{2}{*}{$16 *$} & \multicolumn{2}{|l|}{$t$} & \multicolumn{2}{|c|}{ Fresh Water } & \multirow[b]{2}{*}{$16^{*}$} \\
\hline & & 1 & 8 & 16 & $16 *$ & 1 & 1 & 8 & 16 & & $i$ & 1 & 8 & 16 & \\
\hline Carbon Stel (0.2A\% C) & Curbon Sreel (a.24\% C) & 1905 & 670.6 & 12700 & 1221.7 & 1 & 198.1 & 3988 & 11989 & 1148.1 & 1 & 2159 & s10.s & 6579 & 660.4 \\
\hline 316 Stainless Steel & 316 Swinieas Sted & 0 & 7.6 & 787 & 508 & $i$ & 0 & 25 & 25 & 5.1 & i & 0 & 0 & 0 & 0 \\
\hline 316 Striniess Stoel & Cirboo Sicel $(0.24 \% \mathrm{C})$ & 0.0 & 0.0 & 25 & $50 \infty 0$ & 1 & 25 & 0.0 & 25 & 5.08 & 1 & 0.0 & 0.0 & ao & ao \\
\hline Nickel (99\%) & Curbor Sied (0.24\% C) & a.o & 0.0 & 25 & $\$ 902$ & 1 & 0.0 & 0.0 & 25 & 1118 & 1 & 0.0 & ao & 0.0 & 0.0 \\
\hline Monel (7ONi-30Cu, cold-rolled) & Cirbon Stod (0.24\% C) & 0.0 & 0.0 & 25 & 221.0 & 1 & 0.0 & 00 & 25 & 68.6 & 1 & 0.0 & $\infty$ & 0.0 & 15.2 \\
\hline 70Cu-30Ni Alloy & Carbon Steel (0.24\% C) & 0.0 & 0.0 & 25 & 584 & $\mathfrak{1}$ & 0.0 & 0.0 & 25 & 203 & 1 & 0.0 & ao & 25 & 33.0 \\
\hline Cooper (998) & Curbon Sted (0.24\% O) & 508 & 762 & 177.8 & 1524 & 1 & 508 & 362 & 1524 & 33.0 & $i$ & 0.0 & 25.4 & 762 & 25.4 \\
\hline Carbon Steel $(0.24 \%$ C) & Copper (99\%) & 927.1 & 4864.1 & $\mathbf{M}$ & 647.72 & 1 & 447.0 & 2138.3 & $\mathbf{M}$ & 58932 & 1 & 3607 & 14300 & 1973.6 & 660.4 \\
\hline Crrbon Steel (a.24\% O) & $700 \mathrm{C}-30 \mathrm{Ni}$ Alloy & 9525 & 42875 & $\mathbf{M}$ & $647.7 \mathrm{2}$ & 1 & 589.3 & 24562 & $\mathbf{M}$ & $589.3 x$ & $!$ & 353.1 & 127000 & 1742,4 & 660.4 \\
\hline Carbon Stea $(0.24 \%$ C) & Morel (70Na-30C2, cold-rolled) & 868.7 & 40056 & $M$ & 647.78 & 1 & 591.8 & 2342.9 & 48641 & 1148.1 & 1 & 322.6 & 10160 & 25469 & 711.2 \\
\hline Carbon Sted $(0.24 \%$ C) & Nielad (995) & 10003 & 4445 & $\mathbf{M}$ & 647.72 & 1 & 515.6 & 2194.6 & 4693.9 & 1148.1 & 1 & 299.7 & 1219.2 & 1811.0 & 6604 \\
\hline Carbon Seel $(0.24 \%$ C) & 316 Strimiess Sted & $\$ 81.4$ & 3571.2 & $M$ & 647.72 & $\begin{array}{l}1 \\
1\end{array}$ & 5740 & 200803 & 44552 & 1148.1 & 1 & 2667 & 845.8 & 11278 & 660.4 \\
\hline $2 \operatorname{cin}(99.59)$ & Curbon Sted $(0.24 \% 0)$ & 800.1 & 3761.7 & 4968.2 & 3785 & 1 & 947.4 & 2603.5 & 49327 & 3353 & i & 68.6 & 614.7 & 10947 & 2007 \\
\hline Phosphor Bronase (4Sn-0.25P) & Curbon Sted (0.24\% O) & 25 & 5.1 & 10.2 & 139.7 & 1 & 5.1 & 25 & 102 & 889 & 1 & 25 & 25 & 25 & 17.8 \\
\hline Phosphor Bronze (ASn-0.2SP) & $70 \mathrm{Cn}-30 \mathrm{Ni}$ Alloy & 40.6 & 83.8 & 116.8 & 139.7 & 1 & 178 & 33.0 & 40.6 & 88.9 & $i$ & 25 & 102 & 127 & 17.8 \\
\hline Phosphor Bronze (45n-0.25P) & $70 \mathrm{~N}-30 \mathrm{Cu}$ (cold Rolied) & 68.6 & 16840 & 182377 & 139.7 & 1 & 43.2 & 378.5 & 482.6 & 889 & 1 & 406 & 2235 & 3581 & 17.8 \\
\hline
\end{tabular}

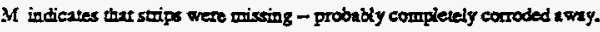

- Yalues listed represent the notent uroupled corrovice losx.

2 indieates that the valief for normal mocourled corrosica loss bas been taken from 8 year corrosion data.

Table 24. Corrosion Penetration for Plate Metal of Galvanic Couples Exposed to Various Waters in the Panama Canal Zone for Periods of up to 16 Years

(Southwell \& Alexander, 1976)

\begin{tabular}{|c|c|c|c|c|c|c|c|c|c|c|c|c|c|c|c|}
\hline \multirow{3}{*}{$\begin{array}{l}\text { Strip } \\
(2 \times 9 \times 1 / 4 \text { in })\end{array}$} & \multirow{3}{*}{$\begin{array}{l}\text { Fit: } \\
\text { (9xisi1/4in) }\end{array}$} & \multicolumn{14}{|c|}{ 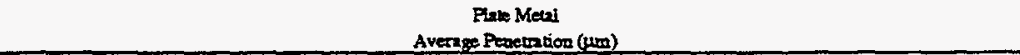 } \\
\hline & & \multicolumn{4}{|c|}{ Sen Vient } & \multirow{2}{*}{$\begin{array}{l}7 \\
1 \\
\end{array}$} & \multicolumn{3}{|c|}{ Men Tide } & \multirow[b]{2}{*}{$16^{*}$} & \multicolumn{2}{|l|}{ i } & \multicolumn{2}{|c|}{ Fresh Waver } & \multirow[b]{2}{*}{$16^{\circ}$} \\
\hline & & 1 & 8 & 16 & $16^{*}$ & & 1 & 8 & 16 & & 1 & 1 & 8 & 16 & \\
\hline Carton Sted $(0.24 \%)$ & Carbon Steel $(0.24 \% C)$ & 172.7 & 609.6 & 1117.6 & 1221.7 & 1 & 2489 & 4547 & 1071.9 & 1148.1 & 1 & 213.4 & 5207 & 6706 & 6004 \\
\hline 316 Striniens Stuel & 316 Strintous Strol & 0 & 152 & 33.0 & 508 & 1 & 0 & 0 & 25.4 & 5.1 & 1 & 0 & 0 & 0 & 0 \\
\hline 316 Sziniless Stoel & Curbon Sted (a.24\% C) & 2007 & 718.8 & 12573 & 1221.7 & 1 & 309.9 & 627.4 & 1110.0 & 11481 & 1 & 203.2 & 675 & 823.0 & 6004 \\
\hline Nielel (999) & Curbon Stzel (0.24\% C) & 195.6 & 759.5 & 12903 & 1221.7 & 1 & 304.8 & 543.6 & 1074.4 & 1148.1 & $t$ & 195.6 & 6020 & 739.1 & 660.4 \\
\hline Monel (70Ni-3 $0 \mathrm{Ca}$, cold-roiled) & Cartion Steel $(0.24 \% 0)$ & 203.2 & 7061 & 13005 & 1221.7 & 1 & 2667 & $\$ 84.2$ & 1087.1 & 11481 & 1 & 2003 & 591.8 & 675.6 & 660.4 \\
\hline 7002-30Ni Alloy & Carton Sted (02460) & 193.0 & 756.9 & 12802 & 1221.7 & 1 & 3124 & 533.4 & 1346.2 & 11481 & 1 & 20007 & 579.1 & 756.9 & 660.4 \\
\hline Copper (99\%) & Curbon Sleel (a.24\% C) & 193.0 & 749.3 & 1394.5 & 1221.7 & 1 & 3023 & $\$ 84.2$ & 1084.6 & 1148.1 & 1 & 198.1 & 607.1 & $m .2$ & 6604 \\
\hline Carbon Steed (0.24\% C) & Coppes (99\%) & 25 & 25 & 73.7 & 152.4 & 1 & 25 & 25 & 127 & 33.0 & 1 & 25 & 25 & 5.1 & 254 \\
\hline Carbon Steel (0.24\% C) & $700 \mathrm{~d}-30 \mathrm{Ni}$ Alloy & 0.0 & 25 & 40.6 & 584 & 1 & 00 & 25 & 25 & 203 & 1 & 0.0 & 5.1 & 7.6 & 33.0 \\
\hline Cartoon Sted $(0.2460)$ & Monel (70Ni-30 ch, exid-rolled) & 0.0 & 25 & 61.0 & 221.0 & 1 & 20 & 25 & 25 & 68.6 & 1 & 0.0 & 0.0 & 0.0 & 15.2 \\
\hline Carboos Stoel (a.24\% C) & Nickel (99\%) & 0.0 & 0.0 & 121.9 & 4826 & 1 & 20 & 25 & 7.6 & 111.8 & 1 & 0.0 & $\infty$ & 5.1 & 0.0 \\
\hline \multirow[t]{2}{*}{ Cerbon Swel (a.24\% C) } & 316 Sninless Sved & 20 & 0.0 & 0.0 & 508 & I & 2.0 & 0.0 & 0.0 & 25 & 1 & 0.0 & 0.0 & 2.0 & 0.0 \\
\hline & & & & & & 1 & & & & & 1 & & & & \\
\hline $\operatorname{Zine}(99.5 \%)$ & Carbon Strel (a 24\% C) & 17.8 & 229 & 393.7 & 1221.7 & 1 & 279 & 229 & sas & 1148.1 & 1 & 178 & 4521 & $\operatorname{sess}$ & 660.4 \\
\hline Phosphor Broare (4Sn-0.25p) & Curton Sted (a.2A\% O) & 1905 & 751.8 & 1399.5 & 1221.7 & 1 & 287.0 & 5664 & 1178.6 & 1148.1 & 1 & 221.0 & 622.3 & 734.1 & 6604 \\
\hline Phouphor Browze (4Sa-a.2SP) & $700 \mathrm{CO} 30 \mathrm{Ni}$ Alloy & 152 & 50.8 & 965 & 58.4 & 1 & 25 & 15.2 & $\mathbf{3 . 4}$ & 203 & 1 & s.2 & 25.4 & 33.0 & 33.0 \\
\hline Phosptor Bronz $\left(4 S_{D}-0.25 P\right)$ & Monel (70Ni-30 Cu, cold-rolled) & 7.6 & 50.8 & 1778 & 21.0 & 1 & 25 & 25.4 & 55.9 & 68.6 & 1 & 0.0 & 102 & 203 & 15.2 \\
\hline
\end{tabular}

$M$ indicutes thry surips were arissing - probably completely cocroded awey.

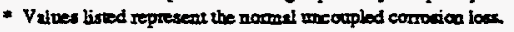

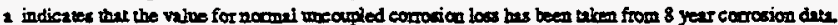


Table 25. Corrosion Damage Data for Bimetallic Coupled Discs Exposed to Various Atmospheres in the Panama Canal Zone for Periods of up to 16 Years

(Southwell \& Alexander, 1976)

\begin{tabular}{|c|c|c|c|c|c|c|c|c|c|c|c|c|c|}
\hline \multirow{2}{*}{\multicolumn{2}{|c|}{ Couple ${ }^{(a)}$}} & \multicolumn{6}{|c|}{ Metal A $\left(\mathrm{g} / \mathrm{m}^{2}\right)$} & \multicolumn{6}{|c|}{ Metal B $\left(\mathrm{g} / \mathrm{m}^{2}\right)$} \\
\hline & & \multicolumn{3}{|c|}{ Coastal } & \multicolumn{3}{|c|}{ Inland } & \multicolumn{3}{|c|}{ Coastal } & \multicolumn{3}{|c|}{ Inland } \\
\hline Metal A & Metal B & 1 & 4 & 16 & 1 & 4 & 16 & 1 & 4 & 16 & 1 & 4 & 16 \\
\hline 70Ni-30Cu (cold Rolled) & $70 \mathrm{Ni}-30 \mathrm{Cu}$ (cold Rolled) & 12 & 23 & 48 & 3 & 10 & 66 & 15 & 51 & 92 & 3 & 9 & 50 \\
\hline Carbon steel $(0.24 \% \mathrm{C})$ & Carbon steel $(0.24 \% \mathrm{C})$ & 631 & 1543 & 3393 & 306 & 691 & 1716 & 535 & 1438 & 3072 & 278 & 637 & 1626 \\
\hline 316 Stainless steel & 316 Stainless steel & 1 & 7 & 54 & 0 & 0 & 35 & 1 & 4 & 66 & 0 & 0 & 50 \\
\hline 70Ni-30Cu (cold Rolled) & Phosphor Bronze (4Sn-0.25P) & 16 & 38 & 92 & 4 & 14 & 53 & 86 & 192 & 638 & 15 & 63 & 187 \\
\hline 70Ni-30Cu (cold Rolled) & Carbon steel $(0.24 \% \mathrm{C})$ & 15 & 23 & 88 & 4 & 9 & 46 & 977 & 2127 & 4547 & 358 & 802 & 2026 \\
\hline 316 Stainless stcel & Carbon steel $(0.24 \% \mathrm{C})$ & 14 & 92 & 98 & 2 & 1 & 53 & 1521 & 3051 & 7298 & 364 & 819 & 2295 \\
\hline Nickel (99\% Ni) & Carbon steel $(0.24 \% \mathrm{C})$ & 13 & 35 & 77 & 2 & 8 & 35 & 1087 & 2029 & 5204 & 315 & 759 & 1854 \\
\hline $70 \mathrm{Cu}-30 \mathrm{Ni}$ Alloy & Carbon steel $(0.24 \% \mathrm{C})$ & 20 & 45 & 160 & 14 & 34 & 136 & 935 & 1904 & 3921 & 347 & 793 & 1944 \\
\hline 70Cu-30Ni Alloy & Phosphor Bronze (4Sn-0.25P) & 21 & 65 & 191 & 12 & 47 & 182 & 106 & 194 & 480 & 9 & 49 & 101 \\
\hline Copper (99\%) & Carbon steel $(0.24 \% \mathrm{C})$ & 67 & 134 & 292 & 37 & 65 & 225 & 942 & 2042 & 4051 & 413 & 971 & 2387 \\
\hline
\end{tabular}

(a) Couples consisted of metal discs of Metal A and of Metal B with approximately equal exposed areas of 0.54 in $^{2}$. 
Table 26. Limiting Temperatures for Some Nickel Base Alloys (Mudge, 1948)

\begin{tabular}{|c|c|c|c|c|c|c|c|c|c|c|c|c|c|c|c|c|}
\hline \multirow{3}{*}{ Material } & \multirow{2}{*}{\multicolumn{6}{|c|}{ Sulfur-Free Atmospheres }} & \multirow{3}{*}{\multicolumn{2}{|c|}{ Steam }} & \multicolumn{8}{|c|}{ Sulfurous Atmospheres } \\
\hline & & & & & & & & & \multicolumn{4}{|c|}{$\begin{array}{l}\text { Temp. Below Which These } \\
\text { Materials May Be Used(a) }\end{array}$} & \multicolumn{4}{|c|}{$\begin{array}{l}\text { Temp. Above Which These } \\
\text { Materials Cannot Be Used }\end{array}$} \\
\hline & \multicolumn{2}{|c|}{ Oxidizing } & \multicolumn{2}{|c|}{ Reducing $\mathrm{H}_{2}$} & \multicolumn{2}{|c|}{ Reducing $\mathrm{CO}$} & & & \multicolumn{2}{|c|}{ Oxidizing } & \multicolumn{2}{|c|}{ Reducing } & \multicolumn{2}{|c|}{ Oxidizing } & \multicolumn{2}{|c|}{ Reducing } \\
\hline Nickel $(99.4 \%)$ & 1050 & 1900 & 1250 & 2300 & 1250 & 2300 & $425-475$ & $800-900$ & 315 & 600 & 250 & 500 & 540 & 1000 & 375 & 700 \\
\hline Monel 400 & 540 & 1000 & 1100 & 2000. & 815 & $1500(\mathrm{~b})$ & $375-425$ & $700-800$ & 315 & 600 & 250 & $500(\mathrm{c})$ & 540 & 1000 & 340 & 650 \\
\hline
\end{tabular}

(a) These materials should not be used above the recommended minimum temperatures without consulting supplier.

(b) Estimated.

(c) Not recommended for use in contact with crude oils containing sulfur at temperatures above $500^{\circ} \mathrm{F}$. 
Table 27. Nominal Composition in Weight Percent of Alloys Exposed to Chloride Solutions (Kolts and Sridhar, 1985)

\begin{tabular}{|l|ccccccccc|c|}
\hline Alloy & $\mathrm{Ni}$ & $\mathrm{Co}$ & $\mathrm{Cr}$ & $\mathrm{Mo}$ & $\mathrm{W}$ & $\mathrm{Fe}$ & $\mathrm{C}$ & $\mathrm{Ti}$ & $\mathrm{Cu}$ & Other \\
\hline Hastelloy Alloy G & bal & 2.5 & 22 & 6.5 & 1 & 19.5 & 0.05 & $\ldots$ & 2 & $2.0(\mathrm{Cb}+\mathrm{Ta})$ \\
Hastelloy Alloy G3 & bal & 5 & 22 & 7 & 1.5 & 19.5 & 0.015 & $\ldots$ & 2 & $0.8 \mathrm{Cb}$ \\
Incoloy Alloy 825 & bal & 2 & 21.5 & 3 & $\ldots$ & 29 & 0.05 & 1 & 2 & $\ldots$ \\
\hline
\end{tabular}




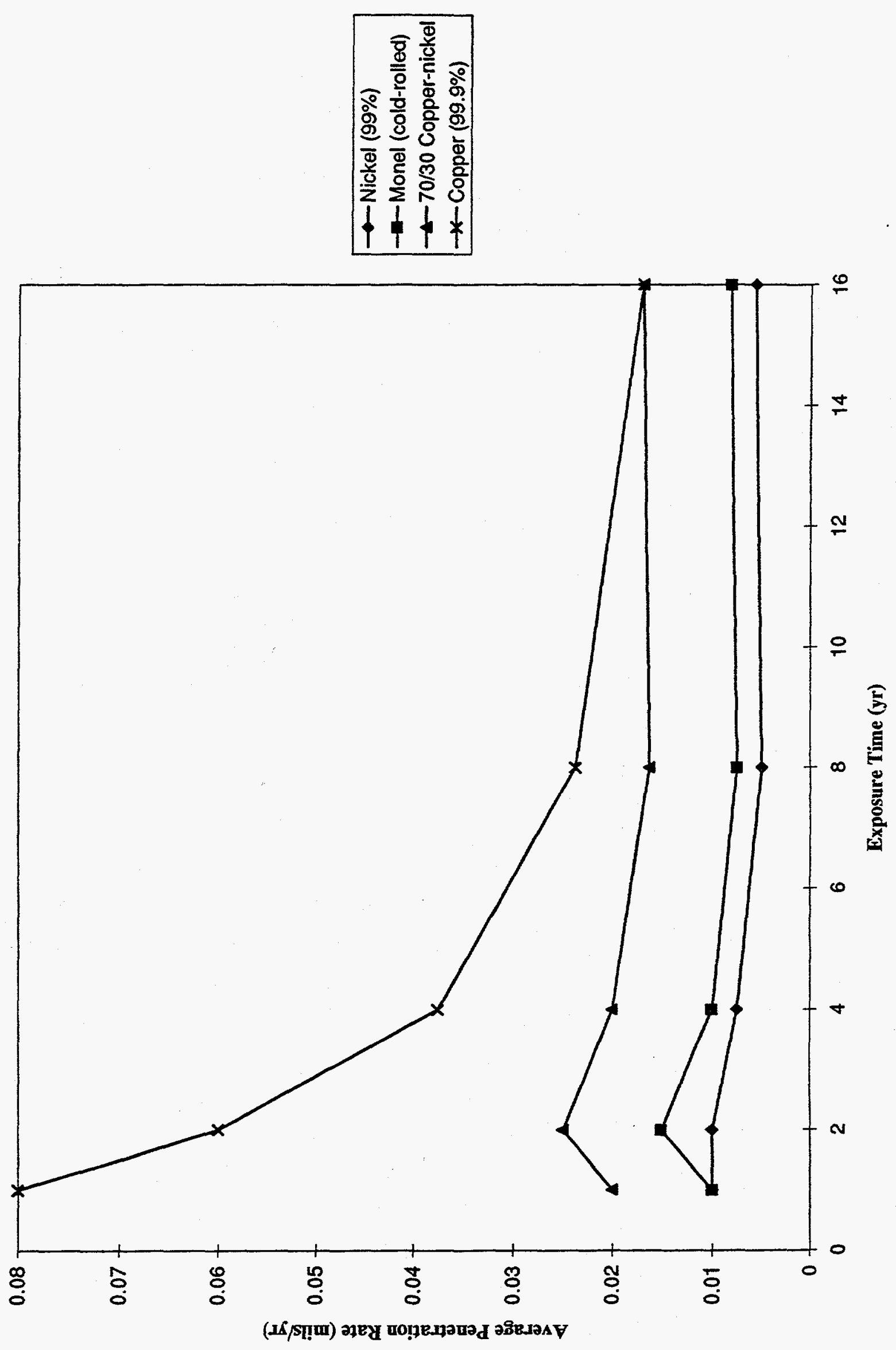

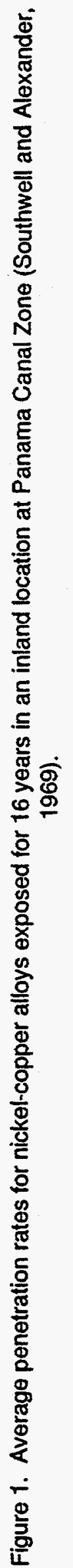




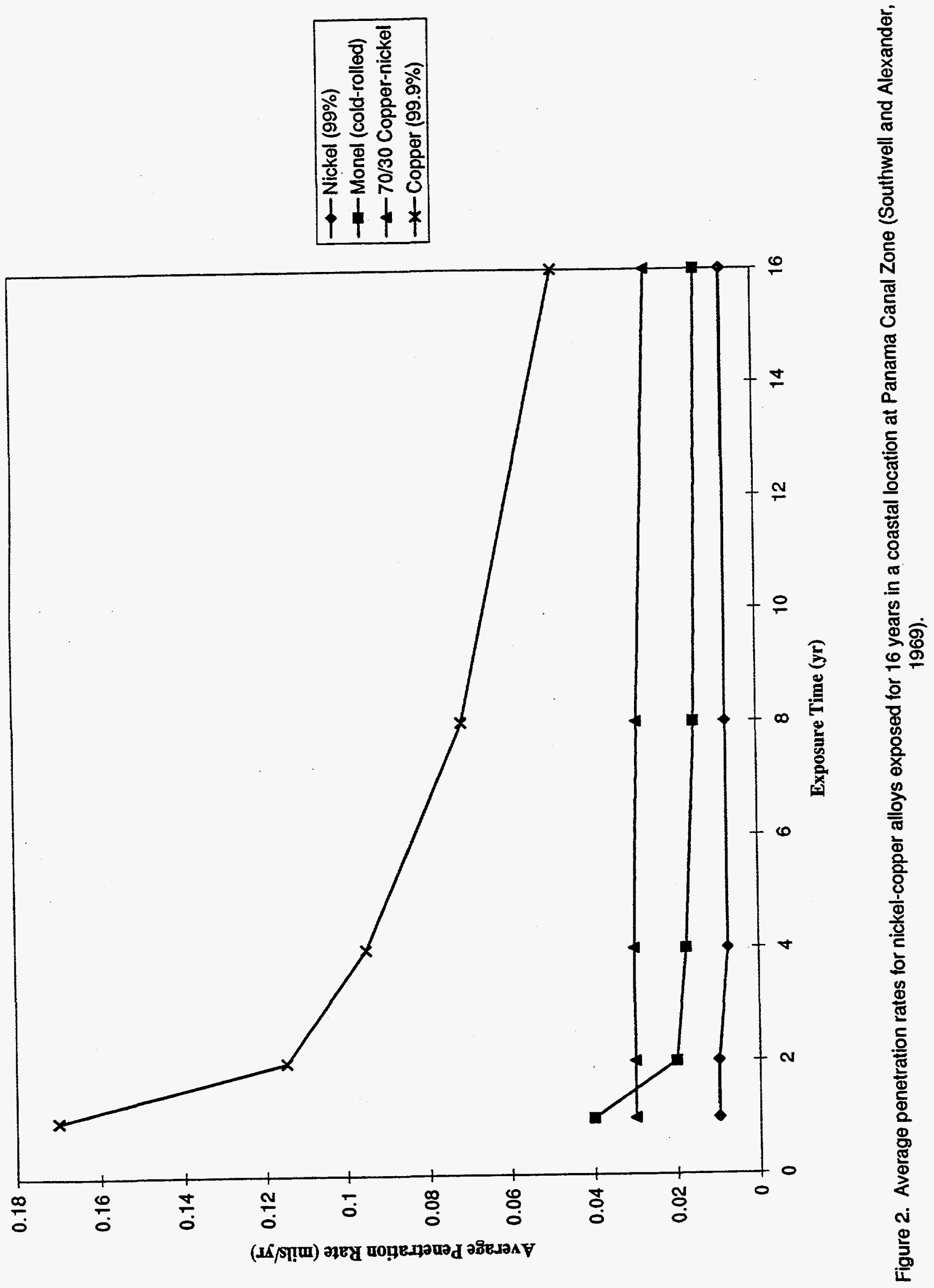




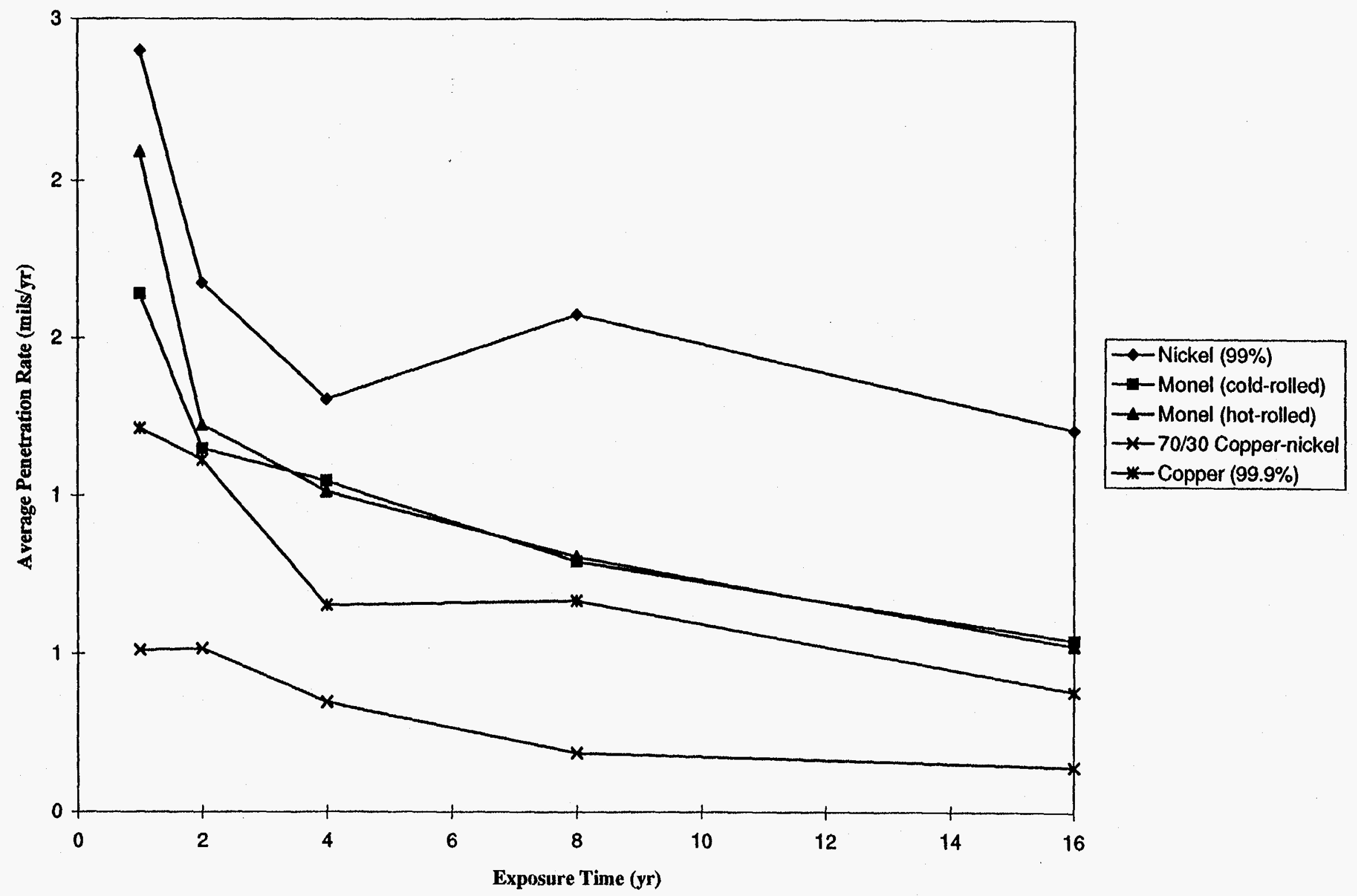

Figure 3. Average penetration rates for nickel-copper alloys exposed for 16 years in the sea water of Panama Canal Zone (Southwell and Alexander, 1969). 

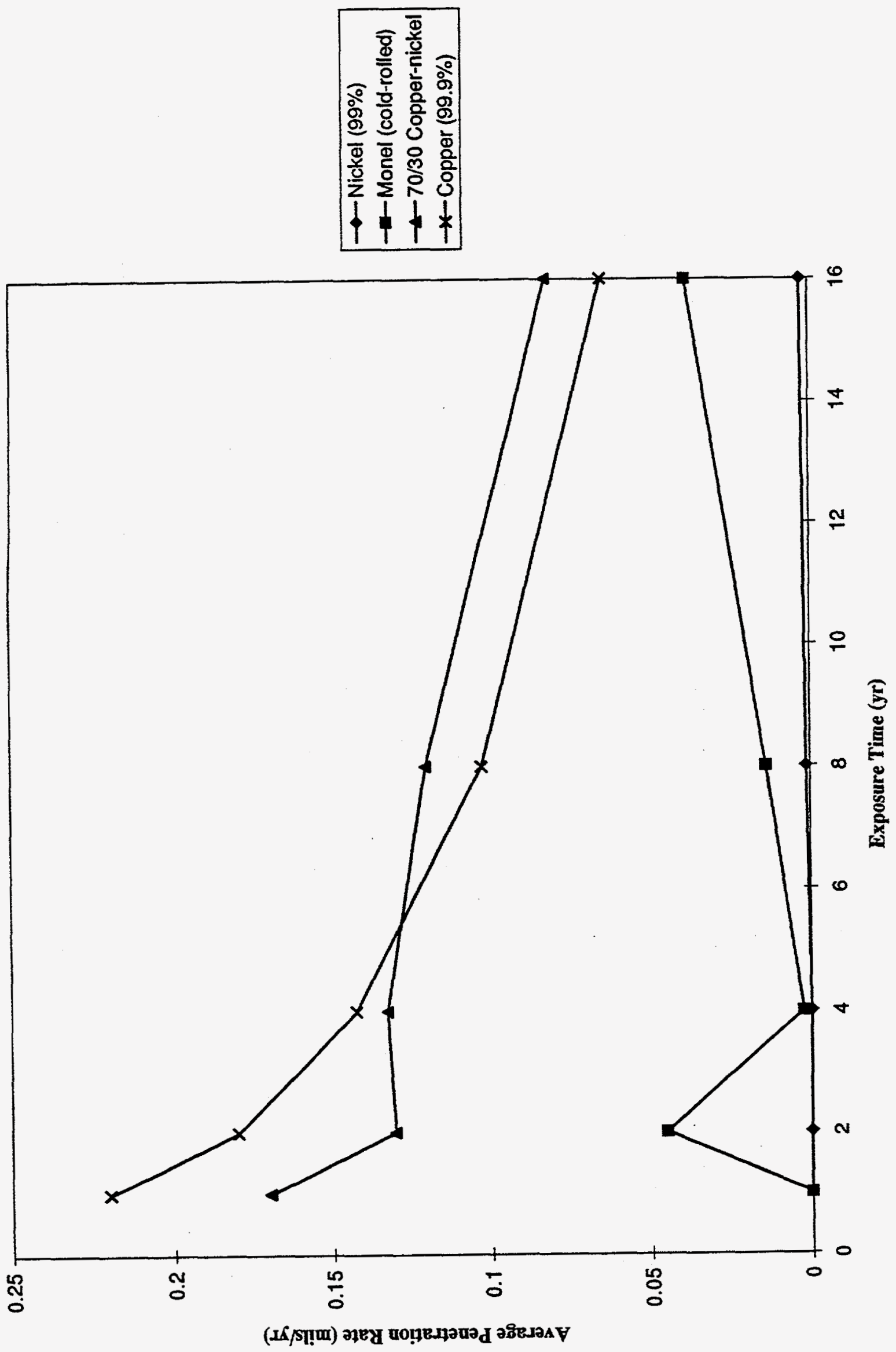

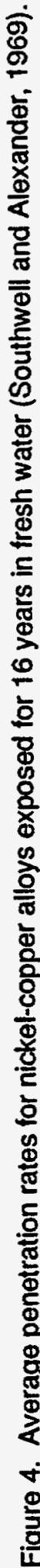




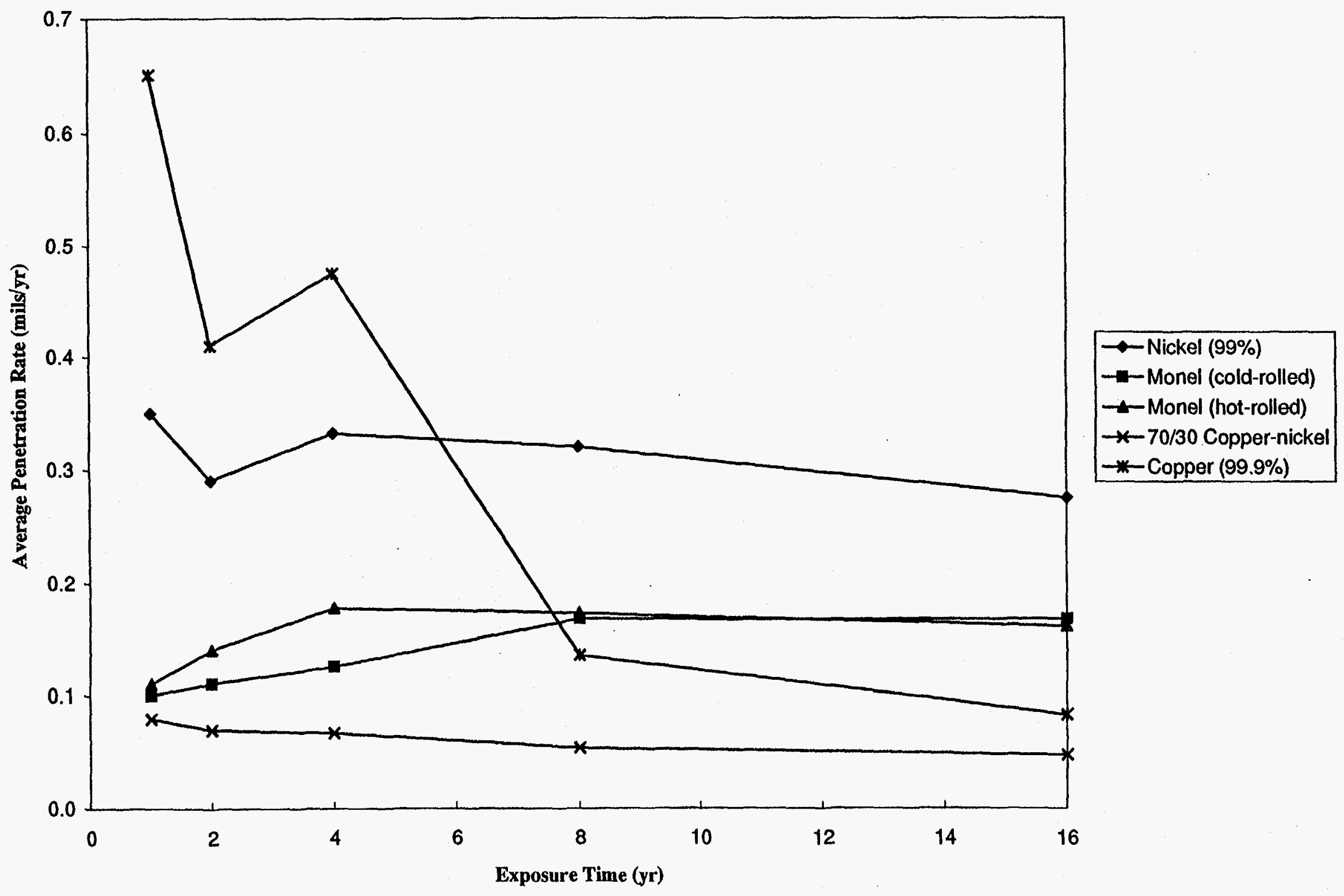

Fioure 5. Average penetration rates for nickel-copper alloys exposed for 16 years at mean tide of Panama Canal Zone (Southwell and Alexander, 1969). 


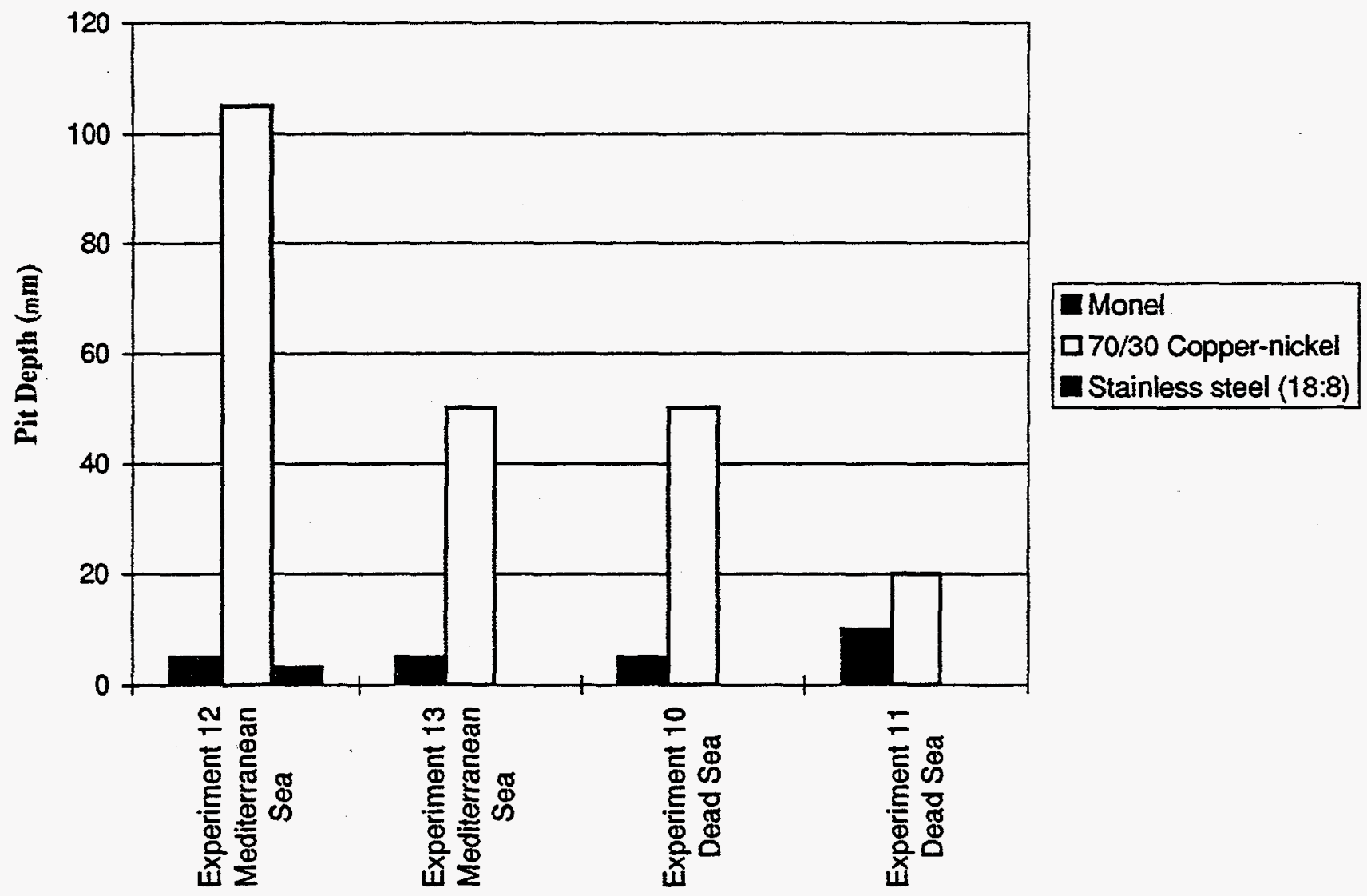

Figure 6. Pit depth of metals exposed for 15 days in jet impingement tests (White, et al., 1966). 


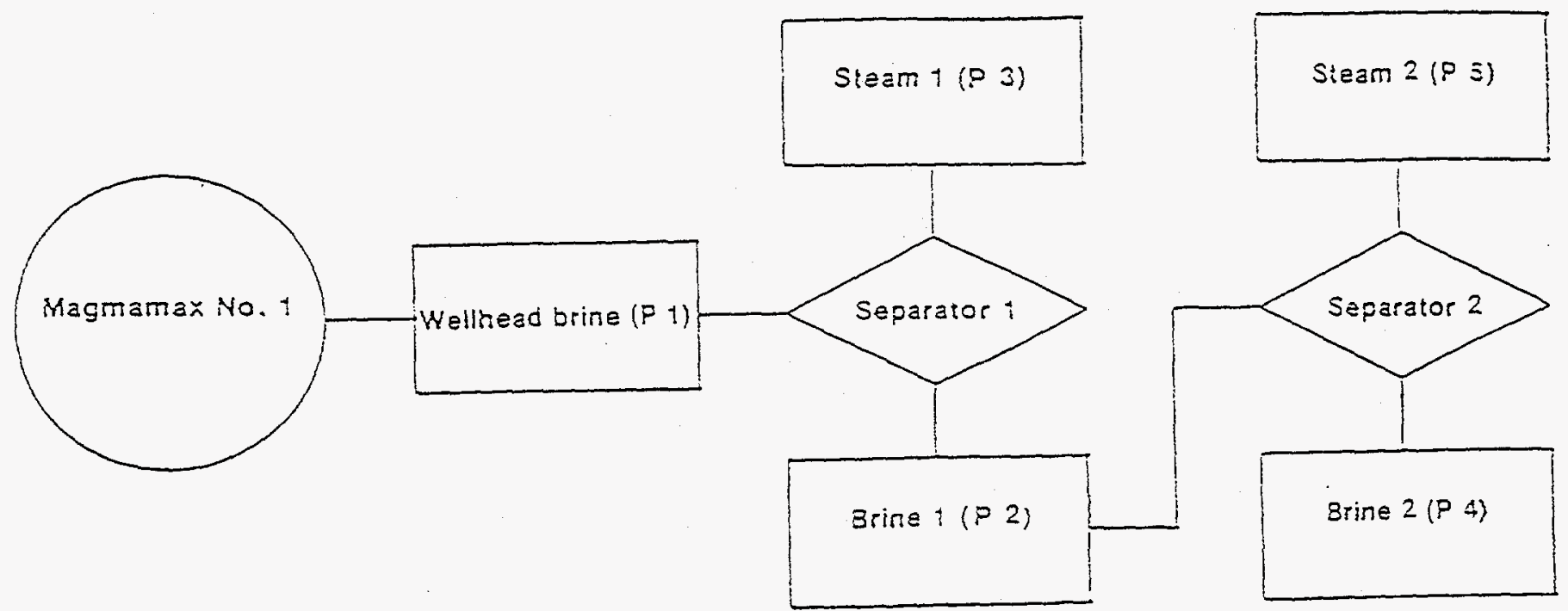

Figure 7: Block diagram of the Bureau of Mines geothermal test facility showing the relative locations of the corrosion test packages (Cramer, et al., 1983). 


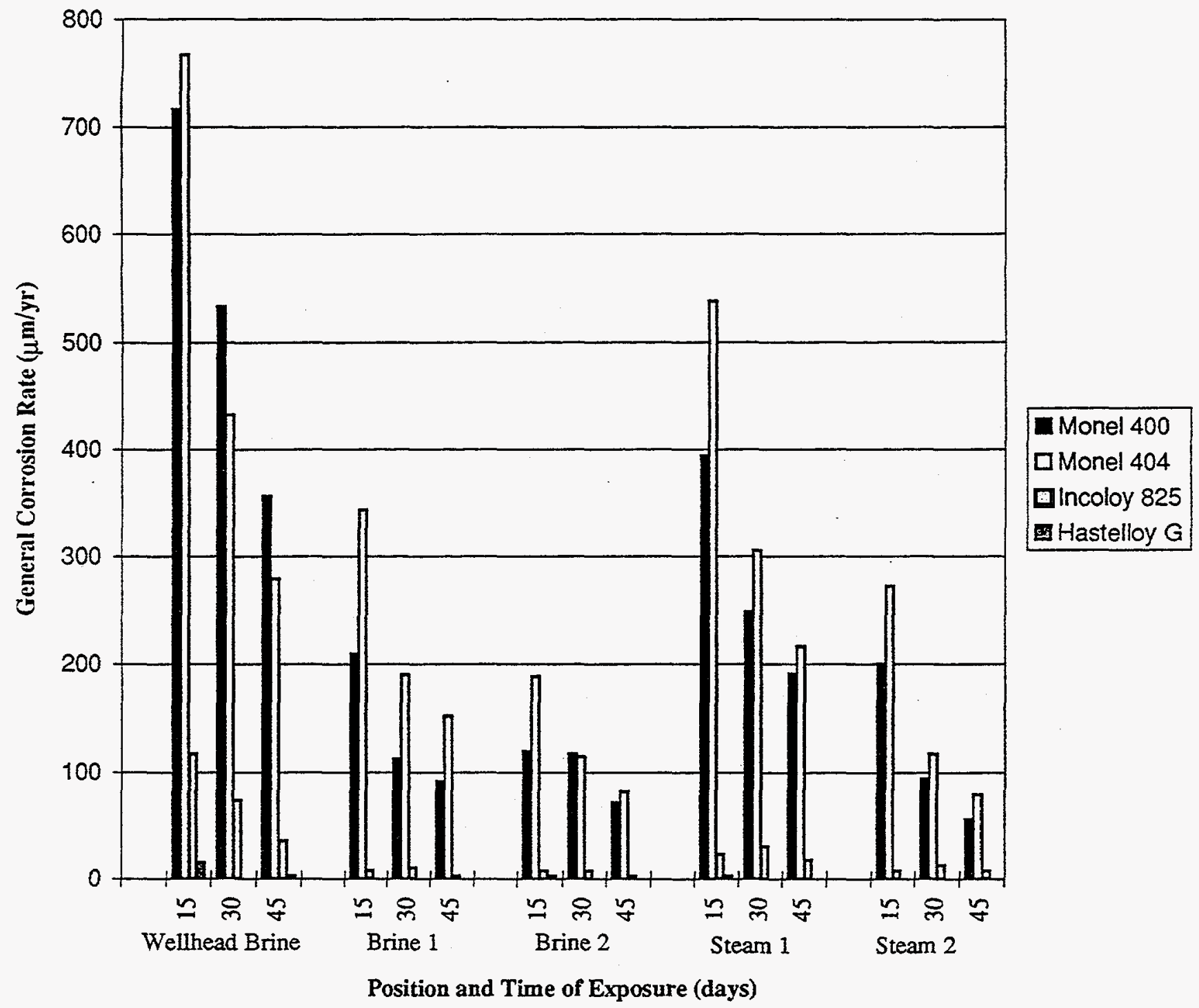

Figure 8. General corrosion rates for nickel alloys in brine and steam (Cramer, et al., 1983). 


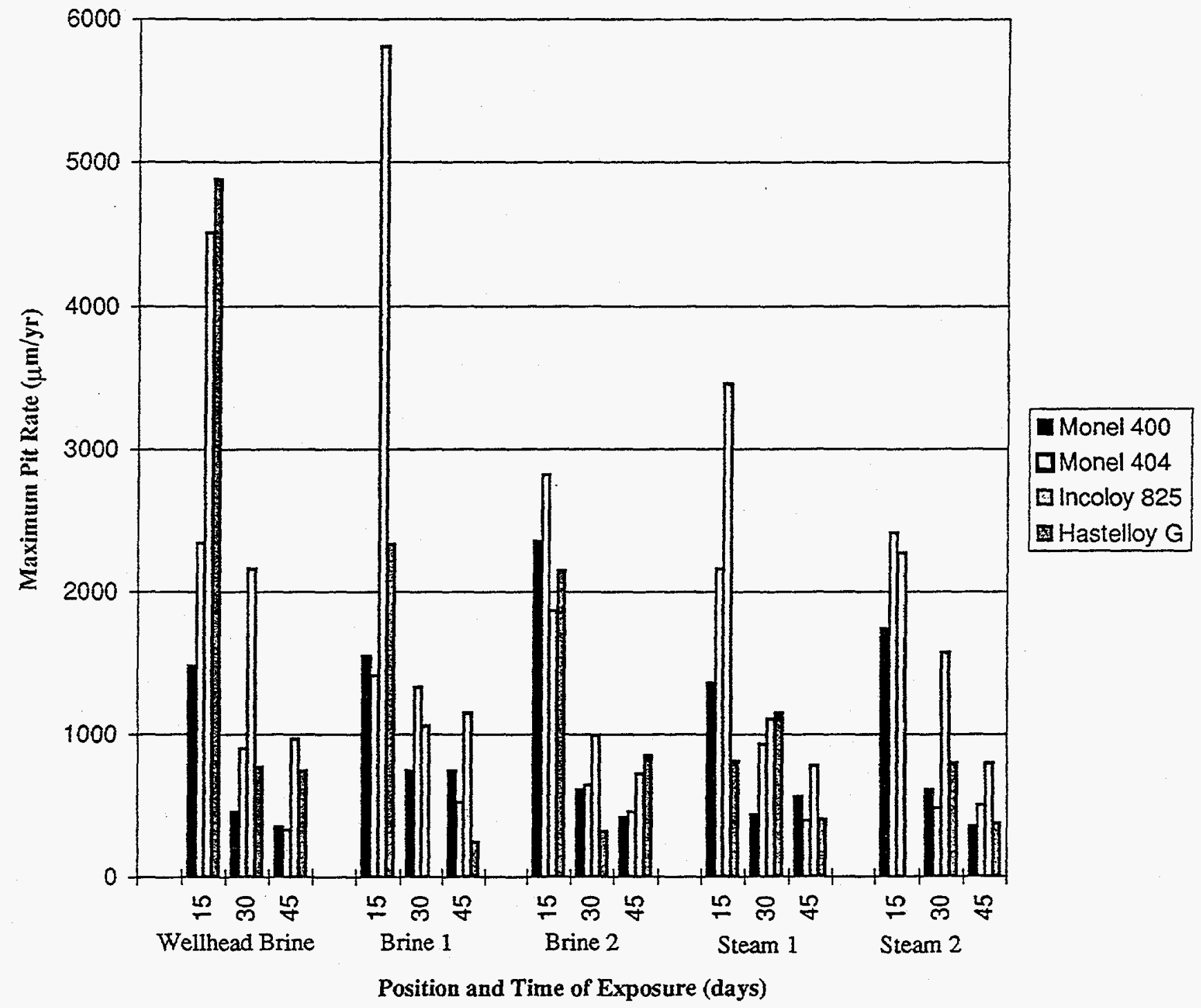

Figure 9. Maximum pit penetration rates for nickel alloys in brine and steam (Cramer, et al., 1983). 
. 


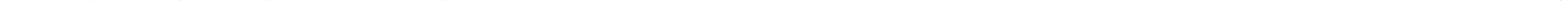




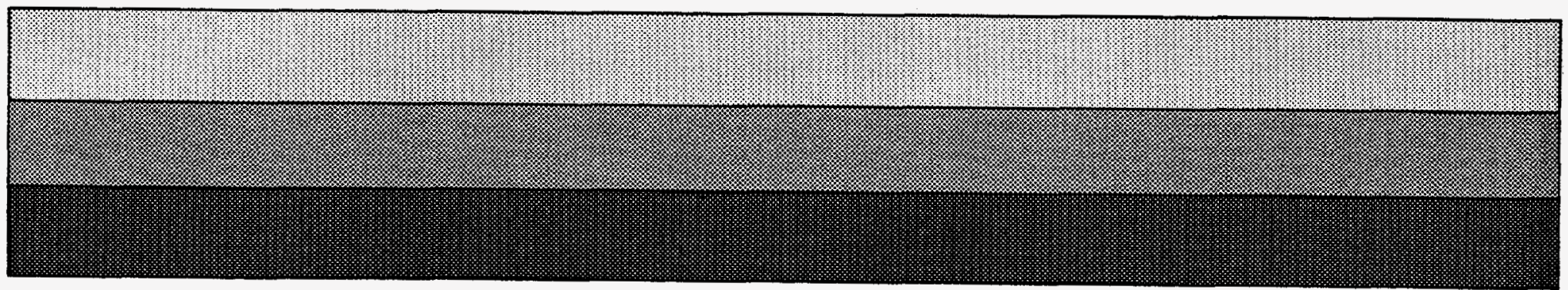

